\title{
IDENTIFICATION OF A CLASS OF HEALTH-OUTCOME DISTRIBUTIONS UNDER A COMMON FORM OF PARTIAL DATA OBSERVABILITY
}

\author{
John Mullahy \\ Working Paper 26011 \\ http://www.nber.org/papers/w26011 \\ NATIONAL BUREAU OF ECONOMIC RESEARCH \\ 1050 Massachusetts Avenue \\ Cambridge, MA 02138 \\ June 2019
}

Thanks are owed to Ciaran O'Neill for helpful comments on an earlier draft. Partial support was provided by RWJF Evidence for Action Grant 73336. The views expressed herein are those of the author and do not necessarily reflect the views of the National Bureau of Economic Research.

NBER working papers are circulated for discussion and comment purposes. They have not been peer-reviewed or been subject to the review by the NBER Board of Directors that accompanies official NBER publications.

(C) 2019 by John Mullahy. All rights reserved. Short sections of text, not to exceed two paragraphs, may be quoted without explicit permission provided that full credit, including ()$^{\circ}$ notice, is given to the source. 
Identification of a Class of Health-Outcome Distributions under a Common Form of Partial

Data Observability

John Mullahy

NBER Working Paper No. 26011

June 2019

JEL No. C25,I1

\begin{abstract}
This paper suggests analytical strategies for obtaining informative parameter bounds when multivariate health-outcome data are partially observed in a particular yet common manner. One familiar context is where $\mathrm{M}>1$ health outcomes' respective totals across $\mathrm{N}>1$ time periods are observed but where questions of interest involve features - probabilities, moments, etc. - of their unobserved joint distribution at each of the $\mathrm{N}$ time periods. For instance, one might wish to understand the distribution of any type of unhealthy day experienced over a month but have access only to the separate totals of physically unhealthy and mentally unhealthy days that are experienced. After demonstrating methods to bound, or partially identify, such distributions and related parameters under several sampling assumptions, the paper proceeds to derive bounds on partial effects involving exogenous covariates. These results are applied in three empirical exercises. Whether the proposed bounds prove to be sufficiently narrow to usefully inform decisionmakers can only be determined in context, although it is suggested in the paper's conclusion that the issues considered in this paper are likely to become increasingly important for analysts.
\end{abstract}

John Mullahy

University of Wisconsin-Madison

Dept. of Population Health Sciences

787 WARF, 610 N. Walnut Street

Madison, WI 53726

and NBER

jmullahy@facstaff.wisc.edu 
'Which reminds me-' the White Queen said, looking down and nervously clasping and unclasping her hands, 'we had such a thunderstorm last Tuesday-I mean one of the last set of Tuesdays, you know.'

Alice was puzzled. 'In our country,' she remarked, 'there's only one day at a time.'

The Red Queen said, 'That's a poor thin way of doing things. Now here, we mostly have days and nights two or three at a time, and sometimes in the winter we take as many as five nights togetherfor warmth, you know.'

\section{Lewis Carroll, Through the Looking-Glass, and What Alice Found There}

\section{Introduction}

Various health surveys pose questions like:

Q1. For how many of the past 30 days was your physical health not good? ... was your mental health not good?

Q2. On how many of the past seven days did you engage in vigorous exercise? ...in moderate exercise?

Q3. On how many of the past 30 days did you smoke cigarettes? ... use electronic vapor products? ... use smokeless tobacco?

Responses to questions like these ${ }^{1}$ reveal some information about how such health indicators are distributed, but do not identify the distribution of related outcomes like:

O1. the number of days on which neither physical nor mental health was good

O2. the number of days on which some exercise was undertaken

O3. the number of days on which some tobacco-related substance was used

\footnotetext{
${ }^{1}$ Similar outcome structures are encountered in clinical settings. For instance, treatments for chronic or episodic migraine may focus on the numbers of monthly migraine days and headache days as outcomes to be assessed (Goadsby et al., 2017; International Headache Society, 2013).
} 
That is, the outcome data are only partially observed in the sense that the specific day-by-day joint distribution of the vector of outcomes is not revealed by responses to questions like Q1-Q3.

It is possible, however, to bound informatively features of probability distributions of outcomes like O1-O3 as well as partial effects of covariates thereon. This paper demonstrates how such bounds can be derived from responses to questions like Q1-Q3 when the responses to Q1-Q3 are themselves either fully (sections 2-4) or partially (section 5) observed.

While this paper is motivated by-and will explore empirically-particular questions where multiple health outcomes or health behaviors are realized over multiple time units, the analytical approaches suggested here are generally applicable. The generic setting is one where each of $\mathrm{N} \geq 2$ units may experience any of $\mathrm{M} \geq 2$ possible binary events. The available data do not reveal whether any particular event $m$ occurs for any particular unit $n$, but the total number of each of the $\mathrm{m}$ events occurring across the $\mathrm{N}$ units is known. The outcome of interest is whether a typical unit experiences any event, and the analytical goal is to learn features of the probability distribution of the number of units experiencing any event. While one is not directly able to learn this from the data, these probabilities can in general be bounded informatively.

Section 2 provides the formal structure, notation, and main results regarding bounds on probabilities, expectations, and quantiles. Section 3 illustrates these ideas with two microdata samples. Section 4 shows how corresponding bounds on partial effects for these parameters can be derived. Section 5 considers the situation where only categorical responses are available ("setmeasured" outcomes), demonstrates how bounds can be derived in such circumstances. Section 6 summarizes.

\section{Bounds with Point-Measured Outcomes}

Assumptions and Preliminaries

$$
\mathrm{y}_{\mathrm{m}, \mathrm{n}} \in\{0,1\} \text { are the outcomes of interest, with } \mathrm{m} \in\{1, \ldots, \mathrm{M}\}, \mathrm{n} \in\{1, \ldots, \mathrm{N}\} \text {, and } \mathrm{M} \text { and }
$$

$\mathrm{N}$ finite, positive integers. For example $\mathrm{y}_{\mathrm{m}, \mathrm{n}}=1$ if outcome $\mathrm{m}$ occurs on day $\mathrm{n}$ and is zero

otherwise. $\mathbf{Y}_{\mathrm{m}}=\left[\mathrm{y}_{\mathrm{m}, \mathrm{n}}\right]$ are $\mathrm{N}$-vectors with joint distribution $\operatorname{Pr}\left(\mathbf{Y}_{1}, \ldots,\left.\mathbf{Y}_{\mathrm{M}}\right|^{\bullet}\right)=\operatorname{Pr}(\mathbf{Y} \mid \bullet)$ where $\bullet$ is a placeholder for possible conditioning on covariates (a consideration addressed in section 4). To reduce clutter $\bullet$ is understood but suppressed until section 4 . 
Define $\mathcal{M}=\{1, \ldots, \mathrm{M}\}, \mathcal{N}=\{0, \ldots, \mathrm{N}\}$, and $\mathcal{N}_{+}=\{1, \ldots, \mathrm{N}\}$. The $\mathrm{y}_{\mathrm{m}, \mathrm{n}}$ are not observed so the joint distribution $\operatorname{Pr}(\mathbf{Y})$ is not identified with the available data. Further, define

$$
\mathrm{S}_{\mathrm{n}}=1\left(\sum_{\mathrm{m} \in \mathcal{M}} \mathrm{y}_{\mathrm{m}, \mathrm{n}}>0\right), \quad \mathrm{n} \in \mathcal{N}_{+}
$$

and

$$
\mathrm{S}=\sum_{\mathrm{n} \in \mathcal{N}_{+}} \mathrm{S}_{\mathrm{n}}=\sum_{\mathrm{n} \in \mathcal{N}_{+}} 1\left(\sum_{\mathrm{m} \in \mathcal{M}^{\mathrm{m}, \mathrm{n}}}>0\right)
$$

Note that $\mathrm{S} \in \mathcal{N}$ and further that neither the $\mathrm{S}_{\mathrm{n}}$ nor $\mathrm{S}$ are observable. $\mathrm{S}$ is the outcome of interest: the number of positive realizations of the binary events $\mathrm{S}_{\mathrm{n}}$ over $\mathcal{N}$. Each $\mathrm{S}_{\mathrm{n}}$ indicates whether at least one of the outcomes $y_{m, n}$ is positive at $n$, for example whether any type of unhealthy day is experienced on day n. The results to follow can be modified to consider more general $\mathrm{S}_{\mathrm{n}}=1\left(\sum_{\mathrm{m} \in \mathcal{M}} \mathrm{y}_{\mathrm{m}, \mathrm{n}}>\mathrm{c}\right)$ but for simplicity the focus is on the baseline case $\mathrm{c}=0$.

The paper's main goal is to demonstrate the use of observable data to identify as tightly as possible the probability distribution of $\mathrm{S}$ across $\mathrm{n}, \mathrm{n} \in \mathcal{N} .^{2}$ It is of interest to learn when $\operatorname{Pr}(\mathrm{S}=\mathrm{n})$ can be point-identified or, when it cannot, to learn the best bounds that can be obtained for set identification. Primary interest may be in identification of the probabilities $\operatorname{Pr}(\mathrm{S}=\mathrm{n})$ themselves or in moments or quantiles of this distribution; moreover interest may focus on the marginal distribution of $\mathrm{S}$ or on its distribution conditional on some covariates $\mathbf{x}$.

To this end define $\mathrm{y}_{\mathrm{m}}=\sum_{\mathrm{n} \in \mathcal{N}_{+}} \mathrm{y}_{\mathrm{m}, \mathrm{n}}$, and let $\mathbf{y}=\left[\mathrm{y}_{1}, \ldots, \mathrm{y}_{\mathrm{M}}\right]$ have joint distribution $\operatorname{Pr}(\mathbf{y})$, which is assumed to be identified nonparametrically by the data. The $\mathrm{y}_{\mathrm{m}}$ are observable in one of two possible ways. The first is where the $\mathrm{y}_{\mathrm{m}}$ are fully or point measured, i.e. where

\footnotetext{
${ }^{2}$ In the specific context where $\mathrm{n}$ indexes time units (days), this translates into identifying the distribution of the number of time units (days) on which no or, reciprocally, any event occurs.
} 
each $\mathrm{y}_{\mathrm{m}}$ is observed exactly as one element in the set $\mathcal{N}$. The second is set measurement, where the true value of $\mathrm{y}_{\mathrm{m}}$ is known to sit in one of $\mathrm{P} \leq \mathrm{N}$ mutually exclusive and exhaustive subsets of $\mathcal{N}$ but where the exact value of the $\mathrm{y}_{\mathrm{m}}$ may not be known. Until section 5 the paper focuses on point-measured $\mathrm{y}_{\mathrm{m}}$, but at that juncture set-measured $\mathrm{y}_{\mathrm{m}}$ are considered.

Table 1 summarizes the structure of the data. The cells highlighted in orange are the observables when the data are point measured.

[Table 1 about here]

It will turn out that in general the bounds derived here are informative, i.e. the bounds intervals $[\mathrm{LB}, \mathrm{UB}]$ are narrower than the theoretically possible values of the parameters of interest. Whether they are sufficiently tight to be useful will depend on the context. Moreover, the focus throughout the paper is on bounds for population parameters, which bounds will themselves be population parameters. While analogy principle estimators (Manski, 1988) are generally available for estimating these bounds, attention in this paper is devoted to identification rather than estimation and inference.

\section{Bounds on Probabilities}

This subsection considers bounds on $\operatorname{Pr}(\mathrm{S}=\mathrm{n}), \mathrm{n} \in \mathcal{N}$. Define $\mathcal{A}=\left\{\mathbf{q} \mid \mathbf{q} \in \mathcal{N}^{\mathrm{M}}\right\} . \mathcal{A}$ contains all the vector values that can be assumed by $\mathbf{y}$; e.g., with $\mathrm{M}=2$ and $\mathrm{N}=2$ $\mathcal{A}=\{[0,0],[1,0],[2,0],[0,1],[1,1],[2,1],[0,2],[1,2],[2,2]\}$. For $\mathrm{n} \in \mathcal{N}$ define

$$
\mathcal{L}(\mathrm{n})= \begin{cases}\left\{\mathbf{q} \mid \mathbf{q} \in \mathcal{A}, \max _{\mathrm{m} \in \mathcal{M}}\left\{\mathrm{q}_{\mathrm{m}}\right\}=\mathrm{n}, \sum_{\mathrm{m} \in \mathcal{M}} \mathrm{q}_{\mathrm{m}}=\mathrm{n}\right\}, & \mathrm{n}<\mathrm{N} \\ \left\{\mathbf{q} \mid \mathbf{q} \in \mathcal{A}, \max _{\mathrm{m} \in \mathcal{M}}\left\{\mathrm{q}_{\mathrm{m}}\right\}=\mathrm{n}\right\}, & \mathrm{n}=\mathrm{N}\end{cases}
$$

and

$$
\mathcal{U}(\mathrm{n})=\left\{\mathbf{q} \mid \mathbf{q} \in \mathcal{A}, \max _{\mathrm{m} \in \mathcal{M}}\left\{\mathrm{q}_{\mathrm{m}}\right\} \leq \mathrm{n}, \sum_{\mathrm{m} \in \mathcal{M}} \mathrm{q}_{\mathrm{m}} \geq \mathrm{n}\right\}
$$


Then the best bounds on $\operatorname{Pr}(\mathrm{S}=\mathrm{n})$ available without additional assumptions are given by

$$
\operatorname{Pr}_{\mathrm{L}}(\mathrm{n})=\operatorname{LB}(\operatorname{Pr}(\mathrm{S}=\mathrm{n}))=\operatorname{Pr}(\mathbf{y} \in \mathcal{L}(\mathrm{n}))
$$

and

$$
\operatorname{Pr}_{\mathrm{U}}(\mathrm{n})=\mathrm{UB}(\operatorname{Pr}(\mathrm{S}=\mathrm{n}))=\operatorname{Pr}(\mathbf{y} \in \mathcal{U}(\mathrm{n}))
$$

Intuitively, for any $\mathrm{n} \in \mathcal{N} \mathcal{L}(\mathrm{n})$ contains the elements of $\mathcal{A}$ that must correspond to $\mathrm{S}=\mathrm{n}$. These vectors will have one element equal to $\mathrm{n}$ and all other $\mathrm{M}-1$ elements equal to zero. No other vectors in $\mathcal{A}$ have the property that the sum of their elements necessarily corresponds to $\mathrm{S}=\mathrm{n}$ even though some of these other vectors in $\mathcal{A}$ could correspond to $\mathrm{S}=\mathrm{n}$. Conversely $\mathcal{U}(\mathrm{n})$ is the set of vectors in $\mathcal{A}$ that could correspond to $\mathrm{S}=\mathrm{n}$ but do not necessarily correspond to $\mathrm{S}=\mathrm{n}$. These vectors contain no element greater than $\mathrm{n}$ (else $\mathrm{S}$ would be greater than $\mathrm{n}$ ), and will contain elements whose sum is at least $n$ (else $S$ would be less than $n$ ).

The sizes of the sets $\mathcal{L}(\mathrm{n})$ and $\mathcal{U}(\mathrm{n})$ depend on $\mathrm{n}$ and $\mathrm{M}$ :

$$
\# \mathcal{L}(\mathrm{n})= \begin{cases}1, & \mathrm{n}=0 \\ \mathrm{M}, & \mathrm{n} \in\{1, \ldots, \mathrm{N}-1\} \\ (\mathrm{n}+1)^{\mathrm{M}}-\mathrm{n}^{\mathrm{M}}, & \mathrm{n}=\mathrm{N}\end{cases}
$$

and

$$
\# \mathcal{U}(\mathrm{n})= \begin{cases}1, & \mathrm{n}=0 \\
(\mathrm{n}+1)^{\mathrm{M}}-\left(\begin{array}{c}
\mathrm{M}+\mathrm{n}-1 \\
\mathrm{M}
\end{array}\right), & \mathrm{n} \in \mathcal{N}_{+}\end{cases}
$$

Note further that $\operatorname{Pr}(\mathrm{S}=0)$ is point identified. That is, $\mathbf{y}=\mathbf{0}$ - which is observable - is the only possible outcome corresponding to $\mathrm{S}=0$. For $\mathrm{n} \in \mathcal{N}_{+}$the width of the bounds interval $\left[\operatorname{Pr}_{L}(n), \operatorname{Pr}_{U}(n)\right]$ will generally exceed zero in the absence of additional narrowing assumptions. 
In some instances determining bounds for a set of possible values of $\mathrm{S}$, not just for single values, may be of interest. ${ }^{3}$ If so, bounds on the relevant set probabilities can be obtained as follows. Let $\mathcal{V} \subset \mathcal{N}$ be the set of interest and, analogous to (3) and (4), define

$$
\mathcal{L}_{\mathrm{v}}(\mathcal{V})=\left\{\mathbf{q} \mid \mathbf{q} \in \mathcal{A}, \max _{\mathrm{m} \in \mathcal{M}}\left\{\mathrm{q}_{\mathrm{m}}\right\} \in \mathcal{V}, \min \left\{\sum_{\mathrm{m} \in \mathcal{M}} \mathrm{q}_{\mathrm{m}}, \mathrm{N}\right\} \in \mathcal{V}\right\}
$$

and

$$
\mathcal{U}_{\mathrm{v}}(\mathcal{V})=\bigcup_{\mathrm{n} \in \mathcal{V}} \mathcal{U}(\mathrm{n})
$$

Then

$$
\operatorname{LB}(\operatorname{Pr}(\mathrm{S} \in \mathcal{V}))=\operatorname{Pr}\left(\mathbf{y} \in \mathcal{L}_{\mathrm{v}}(\mathcal{V})\right)
$$

and

$$
\mathrm{UB}(\operatorname{Pr}(\mathrm{S} \in \mathcal{V}))=\operatorname{Pr}\left(\mathbf{y} \in \mathcal{U}_{\mathrm{v}}(\mathcal{V})\right)
$$

While the upper bounds (12) are obtained as unions of the upper-bound sets (4) across all the elements of $\mathcal{V}$, the lower bounds (11) cannot be computed directly from (3). For instance, suppose $\mathrm{M}=2, \mathrm{~N}=3$, and $\mathcal{V}=\{1,2\}$. While neither $\mathcal{L}(1)=\{[1,0],[0,1]\}$ nor $\mathcal{L}(2)=\{[2,0],[0,2]\}$ contains $\mathbf{q}=[1,1]$ since this value of $\mathbf{q}$ could correspond to either $\mathrm{S}=1$ or $\mathrm{S}=2$, the set $\mathcal{L}_{\mathrm{v}}(\{1,2\})$ does contain $\mathbf{q}=[1,1]$ since this value of $\mathbf{q}$ must correspond to either $\mathrm{S}=1$ or $\mathrm{S}=2$.

\section{Bounds on Moments}

The r-th moment ${ }^{4}$ of $\operatorname{Pr}(\mathrm{S})$ is defined for any $\mathrm{r}>0$ and is given by:

3 E.g., the outcome of interest may be a dichotomization of $\mathrm{S}, 1(\mathrm{~S} \geq \mathrm{t})$ for some threshold $\mathrm{t}$, with the parameter of interest being $\operatorname{Pr}(1(\mathrm{~S} \geq \mathrm{t}))=\operatorname{Pr}(\mathrm{S} \in\{\mathrm{t}, \ldots, \mathrm{N}\}))$.

${ }^{4}$ Before deriving bounds for moments of $\operatorname{Pr}(\mathrm{S})$ it will prove helpful to describe some general results. Suppose for a set of generic parameters $\Theta=\left\{\theta_{j}\right\}$ lower and upper bounds, $\operatorname{LB}\left(\theta_{j}\right)$ and $\operatorname{UB}\left(\theta_{j}\right)$, have been determined. Suppose $h\left(\theta_{j}\right)$ is a smooth, monotone function. Then:

(cont.) 


$$
\mathrm{E}\left[\mathrm{S}^{\mathrm{r}}\right]=\sum_{\mathrm{n} \in \mathcal{N}} \mathrm{n}^{\mathrm{r}} \times \operatorname{Pr}(\mathrm{S}=\mathrm{n})
$$

Since (13) is of the form (from footnote 4) $\sum_{j} h_{j}\left(\theta_{j}\right)$ with $\theta_{j}=\operatorname{Pr}(S=n)$ and $h^{\prime}>0$ one might reasonably consider obtaining bounds on $\mathrm{E}\left[\mathrm{S}^{\mathrm{r}}\right]$ as

$$
\operatorname{LB}\left(\mathrm{E}\left[\mathrm{S}^{\mathrm{r}}\right]\right)=\sum_{\mathrm{n} \in \mathcal{N}} \mathrm{n}^{\mathrm{r}} \times \operatorname{Pr}_{\mathrm{L}}(\mathrm{n})
$$

and

$$
\mathrm{UB}\left(\mathrm{E}\left[\mathrm{S}^{\mathrm{r}}\right]\right)=\sum_{\mathrm{n} \in \mathcal{N}} \mathrm{n}^{\mathrm{r}} \times \operatorname{Pr}_{\mathrm{U}}(\mathrm{n})
$$

While these bounds on $E\left[S^{r}\right]$ will generally be valid, they will also generally not be the tightest possible bounds. To appreciate this, define

(cont.)
(a) $\quad \operatorname{LB}\left(\mathrm{h}\left(\theta_{\mathrm{j}}\right)\right)= \begin{cases}\mathrm{h}\left(\mathrm{LB}\left(\theta_{\mathrm{j}}\right)\right), & \mathrm{h}^{\prime}>0 \\ \mathrm{~h}\left(\mathrm{UB}\left(\theta_{\mathrm{j}}\right)\right) & \mathrm{h}^{\prime}<0\end{cases}$
$\mathrm{UB}\left(\mathrm{h}\left(\theta_{\mathrm{j}}\right)\right)= \begin{cases}\mathrm{h}\left(\mathrm{UB}\left(\theta_{\mathrm{j}}\right)\right), & \mathrm{h}^{\prime}>0 \\ \mathrm{~h}\left(\operatorname{LB}\left(\theta_{\mathrm{j}}\right)\right) & \mathrm{h}^{\prime}<0\end{cases}$
(b)
$\operatorname{LB}\left(\sum_{\mathrm{j}} \mathrm{h}_{\mathrm{j}}\left(\theta_{\mathrm{j}}\right)\right)=\sum_{\mathrm{j}} \operatorname{LB}\left(\mathrm{h}_{\mathrm{j}}\left(\theta_{\mathrm{j}}\right)\right)$
$\mathrm{UB}\left(\sum_{\mathrm{j}} \mathrm{h}_{\mathrm{j}}\left(\theta_{\mathrm{j}}\right)\right)=\sum_{\mathrm{j}} \mathrm{UB}\left(\mathrm{h}_{\mathrm{j}}\left(\theta_{\mathrm{j}}\right)\right)$,

where the summations in (b) run over some or all of the elements of $\Theta$. E.g. (and supposing $\left.\theta_{\mathrm{j}}>0\right): \operatorname{LB}\left(1 / \theta_{\mathrm{j}}\right)=1 / \mathrm{UB}\left(\theta_{\mathrm{j}}\right) ; \quad \mathrm{UB}\left(-\theta_{\mathrm{j}}\right)=-\mathrm{LB}\left(\theta_{\mathrm{j}}\right) ; \quad \mathrm{UB}\left(\theta_{\mathrm{j}}^{2}\right)=\left(\mathrm{UB}\left(\theta_{\mathrm{j}}\right)\right)^{2} ; \quad \operatorname{LB}\left(\theta_{\mathrm{j}}-\theta_{\mathrm{k}}\right)=$ $\operatorname{LB}\left(\theta_{\mathrm{j}}\right)-\mathrm{UB}\left(\theta_{\mathrm{k}}\right)$. Note that even when $\operatorname{LB}\left(\mathrm{h}_{\mathrm{j}}\left(\theta_{\mathrm{j}}\right)\right)$ and $\operatorname{UB}\left(\mathrm{h}_{\mathrm{j}}\left(\theta_{\mathrm{j}}\right)\right)$ are the tightest bounds on each $h_{j}\left(\theta_{j}\right)$ from (a) this does not imply that the bounds on their sums defined in (b) are the tightest possible bounds on $\sum_{\mathrm{j}} \mathrm{h}_{\mathrm{j}}\left(\theta_{\mathrm{j}}\right)$ even though in general the bounds in (b) will be valid. 


$$
\mathcal{L}_{\mathrm{E}}(\mathrm{n})=\left\{\mathbf{q} \mid \mathbf{q} \in \mathcal{A}, \max _{\mathrm{m} \in \mathcal{M}}\left\{\mathrm{q}_{\mathrm{m}}\right\}=\mathrm{n}\right\}
$$

and

$$
\mathcal{U}_{\mathrm{E}}(\mathrm{n})= \begin{cases}\left\{\mathbf{q} \mid \mathbf{q} \in \mathcal{A}, \sum_{\mathrm{m} \in \mathcal{M}} \mathrm{q}_{\mathrm{m}}=\mathrm{n}\right\}, & \mathrm{n}<\mathrm{N} \\ \left\{\mathbf{q} \mid \mathbf{q} \in \mathcal{A}, \sum_{\mathrm{m} \in \mathcal{M}^{\mathrm{m}}} \geq \mathrm{n}\right\}, & \mathrm{n}=\mathrm{N}\end{cases}
$$

The numbers of elements in these sets are given by

$$
\# \mathcal{L}_{\mathrm{E}}(\mathrm{n})=(\mathrm{n}+1)^{\mathrm{M}}-\mathrm{n}^{\mathrm{M}}, \quad \mathrm{n} \in \mathcal{N}
$$

and

$$
\# \mathcal{U}_{\mathrm{E}}(\mathrm{n})= \begin{cases}\left(\begin{array}{c}
\mathrm{M}+\mathrm{n}-1 \\
\mathrm{M}-1
\end{array}\right), & \mathrm{n}<\mathrm{N} \\
(\mathrm{n}+1)^{\mathrm{M}}-\left(\begin{array}{c}
\mathrm{M}+\mathrm{n}-1 \\
\mathrm{M}
\end{array}\right), & \mathrm{n}=\mathrm{N}\end{cases}
$$

For $\mathrm{n} \in \mathcal{N}$, define

$$
\operatorname{Pr}_{\mathrm{E}, \mathrm{L}}(\mathrm{n})=\operatorname{Pr}\left(\mathbf{y} \in \mathcal{L}_{\mathrm{E}}(\mathrm{n})\right)
$$

and

$$
\operatorname{Pr}_{\mathrm{E}, \mathrm{U}}(\mathrm{n})=\operatorname{Pr}\left(\mathbf{y} \in \mathcal{U}_{\mathrm{E}}(\mathrm{n})\right)
$$

Then bounds on $\mathrm{E}\left[\mathrm{S}^{\mathrm{r}}\right]$ that are as least as tight as those in (14) and (15) are given by

$$
\operatorname{LB}_{\mathrm{E}}\left(\mathrm{E}\left[\mathrm{S}^{\mathrm{r}}\right]\right)=\sum_{\mathrm{n} \in \mathcal{N}} \mathrm{n}^{\mathrm{r}} \times \operatorname{Pr}_{\mathrm{E}, \mathrm{L}}(\mathrm{n})
$$

and

$$
\mathrm{UB}_{\mathrm{E}}\left(\mathrm{E}\left[\mathrm{S}^{\mathrm{r}}\right]\right)=\sum_{\mathrm{n} \in \mathcal{N}} \mathrm{n}^{\mathrm{r}} \times \operatorname{Pr}_{\mathrm{E}, \mathrm{U}}(\mathrm{n})
$$


Intuitions for these results may be gleaned by reference to an example summarized in table 2 that describes a case with $\mathrm{M}=2$ and $\mathrm{N}=3$. The cells in panel A of table 2 display the joint probabilities $\operatorname{Pr}(\mathbf{y})=\operatorname{Pr}\left(\mathrm{y}_{1}, \mathrm{y}_{2}\right)$ atop the values of $\mathrm{S}$ that could possibly correspond to each $\left(\mathrm{y}_{1}, \mathrm{y}_{2}\right)$ combination. Note that $\mathrm{S} \in\{0,1,2,3\}$. Panel $\mathrm{B}$ of table 2 shows for this example the corresponding probabilities $\operatorname{Pr}_{L}(n), \operatorname{Pr}_{E, L}(n), \operatorname{Pr}_{U}(n)$, and $\operatorname{Pr}_{E, U}(n)$.

Compare first the columns headed $\operatorname{Pr}_{\mathrm{L}}(\mathrm{n})$ and $\operatorname{Pr}_{\mathrm{E}, \mathrm{L}}(\mathrm{n})$. The entries are the same for $\mathrm{S}=0$ and $\mathrm{S}=3$. For $\mathrm{S}=1$ and $\mathrm{S}=2$ the $\operatorname{Pr}_{\mathrm{E}, \mathrm{L}}(\mathrm{n})$ summands contain probabilities that are absent everywhere in the $\operatorname{Pr}_{\mathrm{L}}(\mathrm{n})$ column (these are shown in blue and orange). These probabilities are absent for $\operatorname{Pr}_{\mathrm{L}}(\mathrm{n})$ since they correspond to values of $\left(\mathrm{y}_{1}, \mathrm{y}_{2}\right)$ associated with multiple possible values of S. Conversely they appear for $\operatorname{Pr}_{E, L}(n)$ since they are assigned to the smallest possible such values of $\mathrm{S}$ to make the smallest possible contributions to the weighted sum in (22); only when assigned thusly can it be assured that (22) will always be a valid lower bound. Thus $\operatorname{Pr}_{E, L}(n) \geq \operatorname{Pr}_{L}(n)$ for all $n$, so that the lower bound in (22) is at least as large as that in (14).

Using analogous reasoning, consider for the upper bound the columns in panel B headed $\operatorname{Pr}_{U}(n)$ and $\operatorname{Pr}_{E, U}(n)$. The joint probabilities corresponding to values of $\left(\mathrm{y}_{1}, \mathrm{y}_{2}\right)$ that could correspond to multiple possible values of $\mathrm{S}$ are assigned to the largest possible such $\mathrm{S}$. While such probabilities (those shown in blue and orange) appear multiple times in the $\operatorname{Pr}_{U}(\mathrm{n})$ column, they appear once and only once in the $\operatorname{Pr}_{E, U}(n)$ column. Thus $\operatorname{Pr}_{E, U}(n) \leq \operatorname{Pr}_{U}(n)$, so that the upper bound in (23) is no larger than the upper bound in (15).

Note that probabilities in the $\operatorname{Pr}_{E, L}(n)$ and $\operatorname{Pr}_{E, U}(n)$ columns sum to one, whereas those in the $\operatorname{Pr}_{\mathrm{L}}(\mathrm{n})$ and $\operatorname{Pr}_{\mathrm{U}}(\mathrm{n})$ columns sum to less than and more than one, respectively. ${ }^{5}$

\footnotetext{
${ }^{5}$ Moreover, for $\mathrm{E}[\mathrm{S}]$ note that (22) and (23) are algebraically equivalent to what might be some readers' intuitive approach of defining a lower bound on $\mathrm{E}[\mathrm{S}]$ as
}

(cont.) 
Bounds on $\operatorname{Var}(S)$

Using the results in footnote 4 , one can bound $\operatorname{Var}(\mathrm{S})$ as

$$
\mathrm{LB}(\operatorname{Var}(\mathrm{S}))=\max \left\{\mathrm{LB}\left(\mathrm{E}\left[\mathrm{S}^{2}\right]\right)-(\mathrm{UB}(\mathrm{E}[\mathrm{S}]))^{2}, 0\right\}
$$

and

$$
\mathrm{UB}(\operatorname{Var}(\mathrm{S}))=\mathrm{UB}\left(\mathrm{E}\left[\mathrm{S}^{2}\right]\right)-(\mathrm{LB}(\mathrm{E}[\mathrm{S}]))^{2}
$$

$\mathrm{LB}\left(\mathrm{E}\left[\mathrm{S}^{2}\right]\right)$ and $\mathrm{UB}\left(\mathrm{E}\left[\mathrm{S}^{2}\right]\right)$ are obtained using $\operatorname{Pr}_{\mathrm{E}, \mathrm{L}}(\mathrm{n})$ and $\operatorname{Pr}_{\mathrm{E}, \mathrm{U}}(\mathrm{n})$ from $(20)$ and $(21)$ as

$$
\operatorname{LB}\left(\mathrm{E}\left[\mathrm{S}^{2}\right]\right)=\sum_{\mathrm{n} \in \mathcal{N}} \mathrm{n}^{2} \times \operatorname{Pr}_{\mathrm{E}, \mathrm{L}}(\mathrm{n})
$$

and

$$
\mathrm{UB}\left(\mathrm{E}\left[\mathrm{S}^{2}\right]\right)=\sum_{\mathrm{n} \in \mathcal{N}} \mathrm{n}^{2} \times \operatorname{Pr}_{\mathrm{E}, \mathrm{U}}(\mathrm{n})
$$

\section{Bounds on Quantiles}

One use of the set-probability bounds in (11) and (12) is in determining bounds on quantiles of $\operatorname{Pr}(\mathrm{S})$. Define for $\alpha \in(0,1)$ the $\alpha$-quantile of $\operatorname{Pr}(\mathrm{S})$ as

(cont.)

$$
\sum_{\mathbf{q} \in \mathcal{A}} \operatorname{Pr}(\mathbf{y}=\mathbf{q}) \times \max _{\mathrm{m} \in \mathcal{M}}\left\{\mathrm{q}_{\mathrm{m}}\right\}
$$

and an upper bound on $\mathrm{E}[\mathrm{S}]$ as

$$
\sum_{\mathbf{q} \in \mathcal{A}} \operatorname{Pr}(\mathbf{y}=\mathbf{q}) \times \min \left\{\sum_{\mathrm{m} \in \mathcal{M}} \mathrm{q}_{\mathrm{m}}, \mathrm{N}\right\} .
$$

See U.S. CDC, 2000, for an application of such an approach. 


$$
\mathrm{Q}_{\mathrm{S}}(\alpha)=\min \{\mathrm{n} \mid \operatorname{Pr}(\mathrm{S} \in\{0, \ldots, \mathrm{n}\}) \geq \alpha\}
$$

Then

$$
\mathrm{LB}\left(\mathrm{Q}_{\mathrm{S}}(\alpha)\right)=\min \{\mathrm{n} \mid \mathrm{UB}(\operatorname{Pr}(\mathrm{S} \in\{0, \ldots, \mathrm{n}\})) \geq \alpha\}
$$

and

$$
\mathrm{UB}\left(\mathrm{Q}_{\mathrm{S}}(\alpha)\right)=\min \{\mathrm{n} \mid \operatorname{LB}(\operatorname{Pr}(\mathrm{S} \in\{0, \ldots, \mathrm{n}\})) \geq \alpha\}
$$

\section{Two Empirical Examples}

The first example uses a sample of 399,155 subjects ages $25+$ from the 2017 Behavioral Risk Factors Surveillance System (BRFSS). ${ }^{6}$ The outcomes of interest are health status outcomes measured by responses to these questions:

Now thinking about your physical health, which includes physical illness and injury, for how many days during the past 30 days was your physical health not good?

Now thinking about your mental health, which includes stress, depression, and problems with emotions, for how many days during the past 30 days was your mental health not good?

As such $\mathrm{M}=2$ and $\mathrm{N}=30$. The sample distributions $\operatorname{Pr}\left(\mathrm{y}_{\mathrm{m}}=\mathrm{n}\right)$ of the two outcomes are depicted in figure 1. In this application $\mathrm{S}$ is the number of days (out of 30) on which individuals are either physically unhealthy or mentally unhealthy.

[Figure 1 about here]

Of interest are bounds on $\operatorname{Pr}(\mathrm{S}=\mathrm{n})$ for $\mathrm{n} \in \mathcal{N}$, on $\mathrm{E}[\mathrm{S}]$ and $\operatorname{Var}(\mathrm{S})$, and on the quantiles $\mathrm{Q}_{\mathrm{S}}(\alpha)$. Applying the results from section 2 provides these bounds. The bounds on

\footnotetext{
${ }^{6}$ https://www.cdc.gov/brfss/index.html
} 
$\mathrm{E}[\mathrm{S}]$ are displayed in panel $\mathrm{A}$ of table 3 , the bounds on the quantiles $\mathrm{Q}_{\mathrm{S}}(\alpha)$ are shown in panel $\mathrm{B}$, and the bounds on the $\operatorname{Pr}(\mathrm{S}=\mathrm{n})$ are depicted in figure 2 and tabulated in table A1. The bounds interval for $\mathrm{E}[\mathrm{S}]$ is .47 days. Lower and upper bounds on $\operatorname{Var}(\mathrm{S})$ are 96.6 and 117.6.

[Figure 2 and Table 3 about here]

The second example is based on a sample of 6,777 adults ages $25+$ from the 2015 Health Survey of England (HSE). ${ }^{7}$ The outcomes of interest are three forms of physical activity measured by responses to these questions:

Think about the time you spent walking in the last 7 days. This includes at work and at home, walking to travel from place to place, and any other walking that you have done solely for recreation, sport, exercise, or leisure. During the last 7 days, on which days did you walk for at least 10 minutes at a time?

Think about all the moderate activities that you did in the last 7 days. Moderate activities refer to activities that take moderate physical effort and make you breathe somewhat harder than normal. Think only about those physical activities that you did for at least 10 minutes at a time. During the last 7 days, on which days did you do moderate physical activities like:

- Digging in the garden,

- Spring cleaning or other heavy housework,

- Gentle swimming or cycling?

Think about all the vigorous activities that you did in the last 7 days. Vigorous physical activities refer to activities that take hard physical effort and make you breathe much harder than normal. Think only about those physical activities that you did for at least 10 minutes at a time. During the last 7 days, on which days did you do vigorous physical activities like:

- Running,

- Fast cycling,

- A workout at the gym that makes you out of breath or sweaty?

Thus $\mathrm{M}=3$ and $\mathrm{N}=7 . \mathrm{S}$ is the number of days (of seven) on which individuals engage in any form of physical activity. The sample distributions of the three outcomes are shown in figure 3.

\footnotetext{
${ }^{7}$ https://digital.nhs.uk/data-and-information/publications/statistical/health-survey-for-england
} 
[Figure 3 about here]

The 2015 HSE is particularly interesting because it provides information not only on the seven-day totals of vigorous, moderate, and walking exercise days but also indicates on which specific day(s) each exercise type occurred. ${ }^{8}$ That is, the data are fully, not partially, observed. This sample was chosen to illustrate how bounds derived as if the data were only partially observed compare with the probabilities, moments, and quantiles actually observed in the data.

The bounds on and observed values of $\mathrm{E}[\mathrm{S}]$ are displayed in Panel A of table 4 while the bounds on and observed values of the quantiles $\mathrm{Q}_{\mathrm{S}}(\alpha)$ are shown in that table's panel $\mathrm{B}$. The corresponding results for each $\operatorname{Pr}(\mathrm{S}=\mathrm{n})$ are pictured in figure 4 and presented in detail in table A2. The bounds interval for $\mathrm{E}[\mathrm{S}]$ is .41 days, while the bounds on $\operatorname{Var}(\mathrm{S})$ are computed to be 3.1 and 11.4 (the observed value of $\operatorname{Var}(\mathrm{S})$ is 7.1 ).

[Figure 4 and Table 4 about here]

\section{Bounding Partial Effects}

Obtaining informative bounds on parameters may sometimes prove sufficient to answer questions at hand. Typical in applied health economics, however, are questions involving partial effects (PEs) of covariates $\mathbf{x}$ on conditional-on-x versions of such parameters, $\theta(\mathbf{x})$. Building on section 2, this section describes strategies for obtaining bounds on such PEs.

Consider the discrete partial effects,

\footnotetext{
${ }^{8}$ Time patterns are considered relevant features of individuals' physical activities. For example, the USDHHS Physical Activity Guidelines for Americans (USDHHS, 2018) recommends:

For substantial health benefits, adults should do at least 150 minutes (2 hours and 30 minutes) to 300 minutes (5 hours) a week of moderate-intensity, or 75 minutes (1 hour and 15 minutes) to 150 minutes (2 hours and 30 minutes) a week of vigorous-intensity aerobic physical activity, or an equivalent combination of moderate- and vigorous-intensity aerobic activity. Preferably, aerobic activity
} should be spread throughout the week. [emphasis added] 


$$
\operatorname{PE}(\theta(\mathbf{x}))=\frac{\Delta \theta(\mathbf{x})}{\Delta \mathbf{x}}=\theta\left(\mathbf{x}_{1}\right)-\theta\left(\mathbf{x}_{0}\right)
$$

where $\mathbf{x}_{0}$ and $\mathbf{x}_{1}$ are distinct values of $\mathbf{x}$. Once bounds on $\theta\left(\mathbf{x}_{0}\right)$ and $\theta\left(\mathbf{x}_{1}\right)$ are determined, the results from footnote 4 provide the basis for deriving bounds on $\operatorname{PE}(\theta(\mathbf{x}))$. That is,

$$
\operatorname{LB}(\operatorname{PE}(\theta(\mathbf{x})))=\operatorname{LB}\left(\theta\left(\mathbf{x}_{1}\right)\right)-\operatorname{UB}\left(\theta\left(\mathbf{x}_{0}\right)\right)
$$

and

$$
\mathrm{UB}(\operatorname{PE}(\theta(\mathbf{x})))=\mathrm{UB}\left(\theta\left(\mathbf{x}_{1}\right)\right)-\operatorname{LB}\left(\theta\left(\mathbf{x}_{0}\right)\right)
$$

These bounds are sign informative if the interval $[\operatorname{LB}(\operatorname{PE}(\theta(\mathbf{x}))), \operatorname{UB}(\operatorname{PE}(\theta(\mathbf{x})))]$ does not straddle zero.

Bounds on continuous PEs, $\partial \theta(\mathbf{x}) / \partial \mathbf{x}$, cannot be computed using this approach, but in many instances these may be approximated reasonably. For example, consider the PE on some parameter $\theta(\mathbf{x})$ of an ostensibly continuous variable like age, which will necessarily be measured coarsely (e.g. one-year increments). As such, one can imagine the "derivative"

$$
\operatorname{PE}\left(\theta\left(\text { age }, \mathbf{x}_{\text {-age }}\right)\right)=\frac{\partial \theta\left(\text { age }, \mathbf{x}_{\text {-age }}\right)}{\partial \text { age }} \approx \frac{\theta\left(\text { age }+1, \mathbf{x}_{\text {-age }}\right)-\theta\left(\text { age }-1, \mathbf{x}_{\text {-age }}\right)}{2}
$$

Thus, using results from footnote 4 ,

$$
\operatorname{LB}\left(\operatorname{PE}\left(\theta\left(\text { age }, \mathbf{x}_{- \text {age }}\right)\right)\right) \approx .5\left(\operatorname{LB}\left(\theta\left(\operatorname{age}+1, \mathbf{x}_{- \text {age }}\right)\right)-\operatorname{UB}\left(\theta\left(\text { age }-1, \mathbf{x}_{\text {-age }}\right)\right)\right)
$$

and 


$$
\mathrm{UB}\left(\operatorname{PE}\left(\theta\left(\text { age }, \mathbf{x}_{\text {-age }}\right)\right)\right) \approx .5\left(\mathrm{UB}\left(\theta\left(\operatorname{age}+1, \mathbf{x}_{- \text {age }}\right)\right)-\operatorname{LB}\left(\theta\left(\text { age }-1, \mathbf{x}_{- \text {age }}\right)\right)\right)
$$

assuming the $\theta\left(\right.$ age $\left.\pm 1, \mathbf{x}_{\text {-age }}\right)$ are identified.

These ideas are applied to the BRFSS and HSE samples. For BRFSS $\mathbf{x}$ contains the binary covariates: age 65+ (vs. age 25-64), female (vs. Male), college graduate (vs. not college graduate), and white non-Hispanic race/ethnicity (vs. other race/ethnicity categories). For HSE $\mathbf{x}$ contains the binary covariates: age 50+ (vs. age 25-49), female (vs. male), college-degree holder (vs. not college-degree holder), and southern England regions (vs. northern). As above, it is possible with the HSE sample to compare the PE bounds with the PEs observed in the data.

In the BRFSS analysis the theoretically possible range for $\mathrm{PE}(\mathrm{E}[\mathrm{S} \mid \mathbf{x}])$ is $[-30,30]$. The estimated bounds on $\mathrm{PE}(\mathrm{E}[\mathrm{S} \mid \mathbf{x}])$ are shown in table 5. For the age, sex, and college-graduate PEs the computed bounds are sign informative. The computed bounds on $\operatorname{PE}(\operatorname{Pr}(\mathrm{S}=\mathrm{n} \mid \mathbf{x}))$ are shown in table A3. For $\mathrm{n} \leq 2$ the bounds for the age-65+ and college-graduate PEs are sign informative, as they are for the college-graduate effect for $n=30$ and the race/ethnicity effect for $\mathrm{n} \leq 1 \quad$ (recall that $\operatorname{PE}(\operatorname{Pr}(\mathrm{S}=0 \mid \mathbf{x}))$ is point identified in the BRFSS sample).

[Table 5 about here]

In the HSE sample the bounds on $\mathrm{PE}(\mathrm{E}[\mathrm{S} \mid \mathbf{x}])$ for age and college degree are sign informative, as seen in table 6 . The partial effects observed in the sample for the four covariates are all close to the midpoints of the bounds intervals. For age $50+$ and college-degree holders the bounds on $\operatorname{PE}(\operatorname{Pr}(S=n \mid \mathbf{x}))$ are sign informative for $n \leq 1$, as shown in table A4 (recall again that $\operatorname{PE}(\operatorname{Pr}(\mathrm{S}=0 \mid \mathbf{x}))$ is point identified in the HSE sample).

[Table 6 about here] 


\section{Bounds with Set-Measured Outcomes}

As noted in section 2 the outcomes $\mathbf{y}$ available in the data may themselves be only partially observable, i.e. not point measured. Yet while the exact values of the $\mathrm{y}_{\mathrm{m}}$ may not be observed in the data it is known in which of $\mathrm{P}$ observed sets of values each $\mathrm{y}_{\mathrm{m}}$ resides. Such data are called here set measured, but they are also known as interval measured.

Consider the outcome set $\mathcal{N}$ as a sequence containing $\mathrm{P}$ consecutive subsequences $\mathrm{K}_{\mathrm{p}}$, $\mathrm{p} \in \mathcal{P}=\{1, \ldots, \mathrm{P}\}, \mathrm{P}<\mathrm{N}+1 .{ }^{9}$ Thus, $\mathcal{N}=\left\{\mathrm{K}_{1}, \ldots, \mathrm{K}_{\mathrm{P}}\right\}$ with $\mathrm{K}_{\mathrm{p}}=\left\{\mathrm{k}_{\mathrm{p}, \min }, \ldots, \mathrm{k}_{\mathrm{p}, \max }\right\}, \mathrm{k}_{1, \min }=0$ $\mathrm{k}_{\mathrm{P}, \max }=\mathrm{N}$. Some of the $\mathrm{K}_{\mathrm{p}}$ may be singletons where $\mathrm{k}_{\mathrm{p}, \min }=\mathrm{k}_{\mathrm{p}, \max }$.

For concreteness consider information on youth tobacco use from the 2017 Youth Risk Behavior Surveillance System (YRBSS), ${ }^{10}$ a sample of 12,548 observations on high-school students. The outcomes of interest are measured by the responses to four questions:

During the past 30 days, on how many days did you...

... smoke cigarettes

...use an electronic vapor product

... use chewing tobacco, snuff, dip, snus, or dissolvable tobacco products

...smoke cigars, cigarillos, or little cigars

Thus $\mathrm{M}=4$ and $\mathrm{N}=30$. Possible responses are categorized as: 0 days; 1 or 2 days; 3 to 5 days; 6 to 9 days; 10 to 19 days; 20 to 29 days; all 30 days. As such one has $\mathrm{P}=7$ with $\mathrm{K}_{1}=\{0\}$, $\mathrm{K}_{2}=\{1,2\}, \mathrm{K}_{3}=\{3,4,5\}, \mathrm{K}_{4}=\{6, \ldots, 9\}, \mathrm{K}_{5}=\{10, \ldots, 19\}, \mathrm{K}_{6}=\{20, \ldots, 29\}$, and $\mathrm{K}_{7}=\{30\}$.

The observed $\operatorname{Pr}\left(\mathrm{y}_{\mathrm{m}} \in \mathrm{K}_{\mathrm{p}}\right)$ for the four outcomes are depicted in figure 5 . In this application $\mathrm{S}$ is the number of days (out of 30) on which subjects use any tobacco-related product. Understanding the use of multiple substances is an active area of research (Pesko et al., 2016).

[Figure 5 about here]

\footnotetext{
9 If $\mathrm{P}=\mathrm{N}+1$ the $\mathrm{y}_{\mathrm{m}}$ would be fully point measured.

${ }^{10}$ https://www.cdc.gov/healthyyouth/data/yrbs/index.htm
} 
With set-measured outcomes the $\operatorname{Pr}\left(\mathrm{y}_{\mathrm{m}} \in \mathrm{K}_{\mathrm{p}}\right)$ are generally identified while the probabilities $\operatorname{Pr}\left(\mathrm{y}_{\mathrm{m}}=\mathrm{n}\right)$ will not be point identified for at least some $\mathrm{n}$. Without information on $\operatorname{Pr}\left(\mathrm{y}_{\mathrm{m}}=\mathrm{n}\right)$ for all $\mathrm{n} \in \mathcal{N} \quad \mathrm{E}\left[\mathrm{y}_{\mathrm{m}}\right]$ will not generally be point identified. However the $\mathrm{E}\left[\mathrm{y}_{\mathrm{m}}\right]$ can be bounded as can $\operatorname{Pr}(\mathrm{S}=\mathrm{n})$ and $\mathrm{E}\left[\mathrm{S}^{\mathrm{r}}\right]$. If $\mathrm{K}_{1}=\{0\}$ then $\operatorname{Pr}(\mathrm{S}=0)$ is point identified.

Consider first bounds on the $\mathrm{E}\left[\mathrm{y}_{\mathrm{m}}\right]$. The idea (Manski, 1989; Manski and Tamer, 2002) is to compute bounds as pseudo-means as if all probability mass in a given $K_{p}$ is assigned to its minimum value $\mathrm{k}_{\mathrm{p}, \min }\left(\right.$ for $\mathrm{LB}\left(\mathrm{E}\left[\mathrm{y}_{\mathrm{m}}\right]\right)$ ) or its maximum value $\mathrm{k}_{\mathrm{p}, \max }\left(\right.$ for $\mathrm{UB}\left(\mathrm{E}\left[\mathrm{y}_{\mathrm{m}}\right]\right)$ ), i.e.

$$
\mathrm{LB}\left(\mathrm{E}\left[\mathrm{y}_{\mathrm{m}}\right]\right)=\sum_{\mathrm{p} \in \mathcal{P}} \mathrm{k}_{\mathrm{p}, \min } \times \operatorname{Pr}\left(\mathrm{y}_{\mathrm{m}} \in \mathrm{K}_{\mathrm{p}}\right)
$$

and

$$
\mathrm{UB}\left(\mathrm{E}\left[\mathrm{y}_{\mathrm{m}}\right]\right)=\sum_{\mathrm{p} \in \mathcal{P}} \mathrm{k}_{\mathrm{p}, \max } \times \operatorname{Pr}\left(\mathrm{y}_{\mathrm{m}} \in \mathrm{K}_{\mathrm{p}}\right)
$$

To obtain bounds on $\operatorname{Pr}(\mathrm{S}=\mathrm{n})$ one follows the same strategy as in section 2, but with set-measured outcomes each bound so derived applies to the set probability $\operatorname{Pr}\left(\mathrm{S} \in \mathrm{K}_{\mathrm{p}}\right)$ instead of to the point probability $\operatorname{Pr}(\mathrm{S}=\mathrm{n})$. However, since every element in each $\mathrm{K}_{\mathrm{p}}$ could have have probability as small as $\mathrm{LB}\left(\operatorname{Pr}\left(\mathrm{S} \in \mathrm{K}_{\mathrm{p}}\right)\right)$ or as large as $\mathrm{UB}\left(\operatorname{Pr}\left(\mathrm{S} \in \mathrm{K}_{\mathrm{p}}\right)\right)$ then each element of $K_{p}$ is assigned these values as $\operatorname{LB}(\operatorname{Pr}(S=n))$ and $U B(\operatorname{Pr}(S=n))$ for $n \in K_{p}$. Using these bounds on each $\operatorname{Pr}(\mathrm{S}=\mathrm{n})$ then allows one to compute bounds on $\mathrm{E}[\mathrm{S}]$ exactly as in section 2 .

Table 7 shows the $\operatorname{Pr}\left(\mathrm{y}_{\mathrm{m}}=\mathrm{n}\right)$ assigned from the observed $\operatorname{Pr}\left(\mathrm{y}_{\mathrm{m}} \in \mathrm{K}_{\mathrm{p}}\right)$, with the former used in turn to compute bounds on the $\mathrm{E}\left[\mathrm{y}_{\mathrm{m}}\right]$ as in (36) and (37). Bounds on the $\operatorname{Pr}\left(\mathrm{S} \in \mathrm{K}_{\mathrm{p}}\right)$ are depicted in figure 6 and tabulated, along with those for the corresponding $\operatorname{Pr}(\mathrm{S}=\mathrm{n})$, in table A5. Table A5 also shows the $\operatorname{Pr}_{\mathrm{E}, \mathrm{L}}(\mathrm{n})$ and $\operatorname{Pr}_{\mathrm{E}, \mathrm{U}}(\mathrm{n})$ used used to compute 
the bounds on $\mathrm{E}[\mathrm{S}]$ reported in table 7 . With these bounds, and given relevant covariates $\mathbf{x}$, one could compute partial-effect bounds exactly as in section 4 .

[Figure 6 and Table 7 about here]

\section{Summary}

This paper has suggested approaches for obtaining bounds on parameters of interest when multivariate outcome data are partially observed in a particular yet familiar manner. The approaches proposed here will generally result in informative bounds, as demonstrated in three empirical exercises. Whether such bounds will be sufficiently informative to satisfy decisionmakers' requirements can only be determined in context.

Issues akin to those addressed here may be increasingly salient. Statistical agencies are acting to protect against confidentiality-threatening data disclosure, and are doing so in part by using various strategies that amount to creating different forms of partially-observable measures in public-use samples (see Abowd and Schmutte, 2019, for an interesting assessment).

For example, the public-use samples of the Medical Expenditure Panel Survey (MEPS) previously contained information on specific dates on which respondents used various healthcare services. Recently, however, only the months in which services are obtained have been provided in public-use samples. In such contexts approaches like those suggested here can be used to bound features of the probability distributions of outcomes like "contact days" or "healthy days at home" (Bynum, et al., 2016; Burns and Mullahy, 2016; Slabaugh et al., 2017).

\section{Acknowledgments}

Thanks are owed to Ciaran O'Neill for helpful comments on an earlier draft. Partial support was provided by RWJF Evidence for Action Grant 73336. 


\section{References}

Abowd, J.M. and I.M. Schmutte. 2019. "An Economic Analysis of Privacy Protection and Statistical Accuracy as Social Choices." American Economic Review 109: 171-202.

Burns, M. and J. Mullahy. 2016. "Healthy-Time Measures of Health Outcomes and Healthcare Quality." NBER W.P. 22562.

Bynum, J.P.W. et al. 2016. Our Parents, Ourselves: Health Care for an Aging Population. Lebanon, NH: The Dartmouth Institute of Health Policy and Clinical Practice.

Goadsby, P.J. et al. 2017. "A Controlled Trial of Erenumab for Episodic Migraine." NEJM 377: 2123-2132.

International Headache Society. 2013. "The International Classification of Headache Disorders, 3rd edition (beta version)." Cephalagia 33: 629-808.

Manski, C.F. 1988. Analog Estimation Methods in Econometrics. New York: Chapman and Hall.

Manski, C.F. 1989. "Anatomy of the Selection Problem." Journal of Human Resources 24: 343360.

Manski, C.F. and E. Tamer. 2002. "Inference on Regressions with Interval Data on a Regressor or Outcome." Econometrica 70: 519-546.

Pesko, M.F. et al. 2016. "The Effect of Potential Electronic Nicotine Delivery System Regulations on Nicotine Product Selection." Addiction 111: 734-744.

Slabaugh, S.L. et al. 2017. "Leveraging Health-Related Quality of Life in Population Health Management: The Case for Healthy Days." Population Health Management 20: 13-22.

U.S. Centers for Disease Control and Prevention. 2000. Measuring Healthy Days. Atlanta: CDC.

U.S. Department of Health and Human Services. Physical Activity Guidelines for Americans, 2nd edition. Washington, DC: U.S. Department of Health and Human Services; 2018. 
Figure 1

2017 BRFSS Sample: Sample Distributions of Physically and Mentally Unhealthy Days

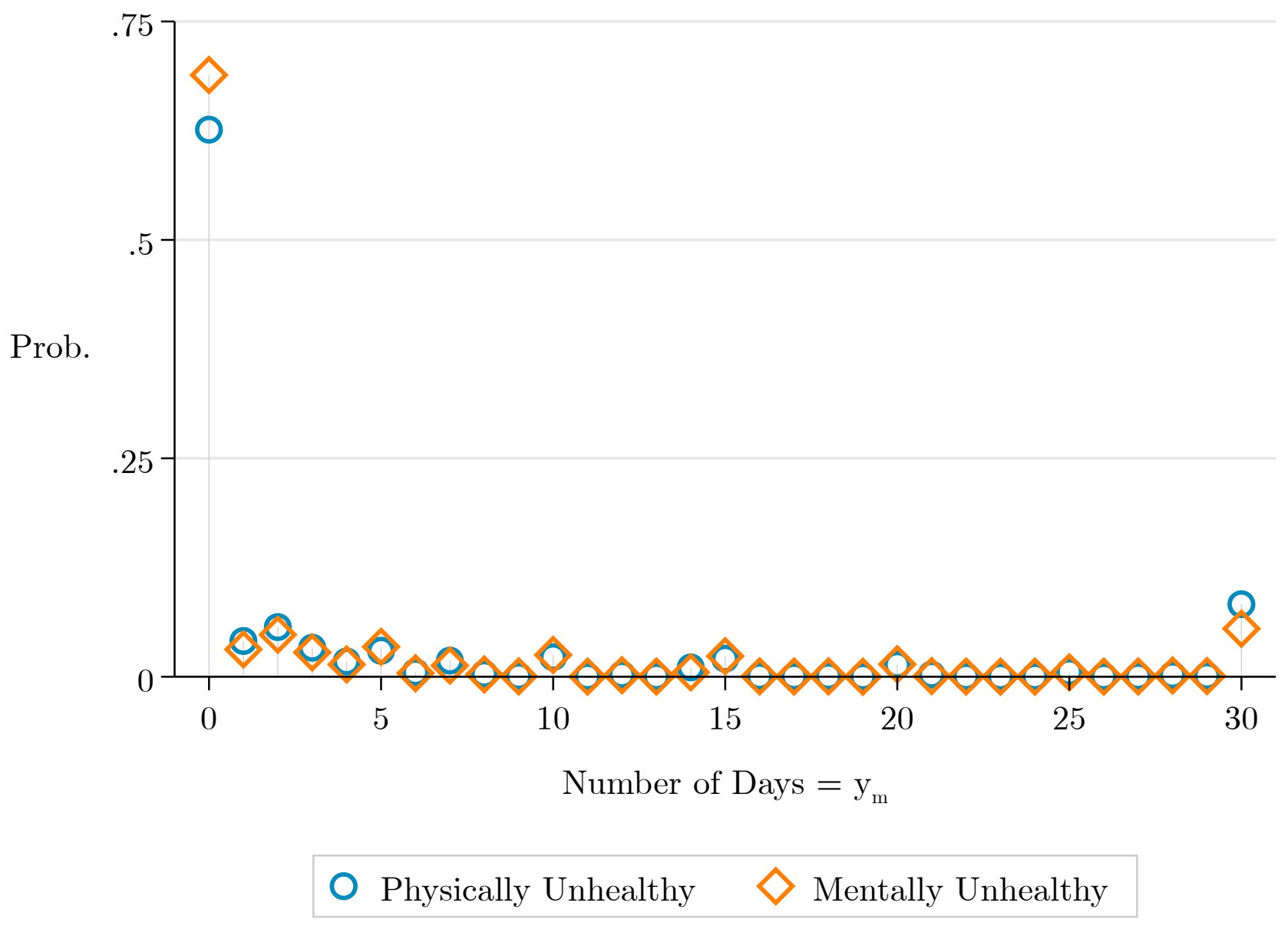


Figure 2

2017 BRFSS Sample: Upper and Lower Bounds on $\operatorname{Pr}(\mathrm{S}=\mathrm{n})$ for $\mathrm{n}>0$;

$$
\operatorname{Pr}(\mathrm{S}=0) \text { is point-identified at } .494
$$

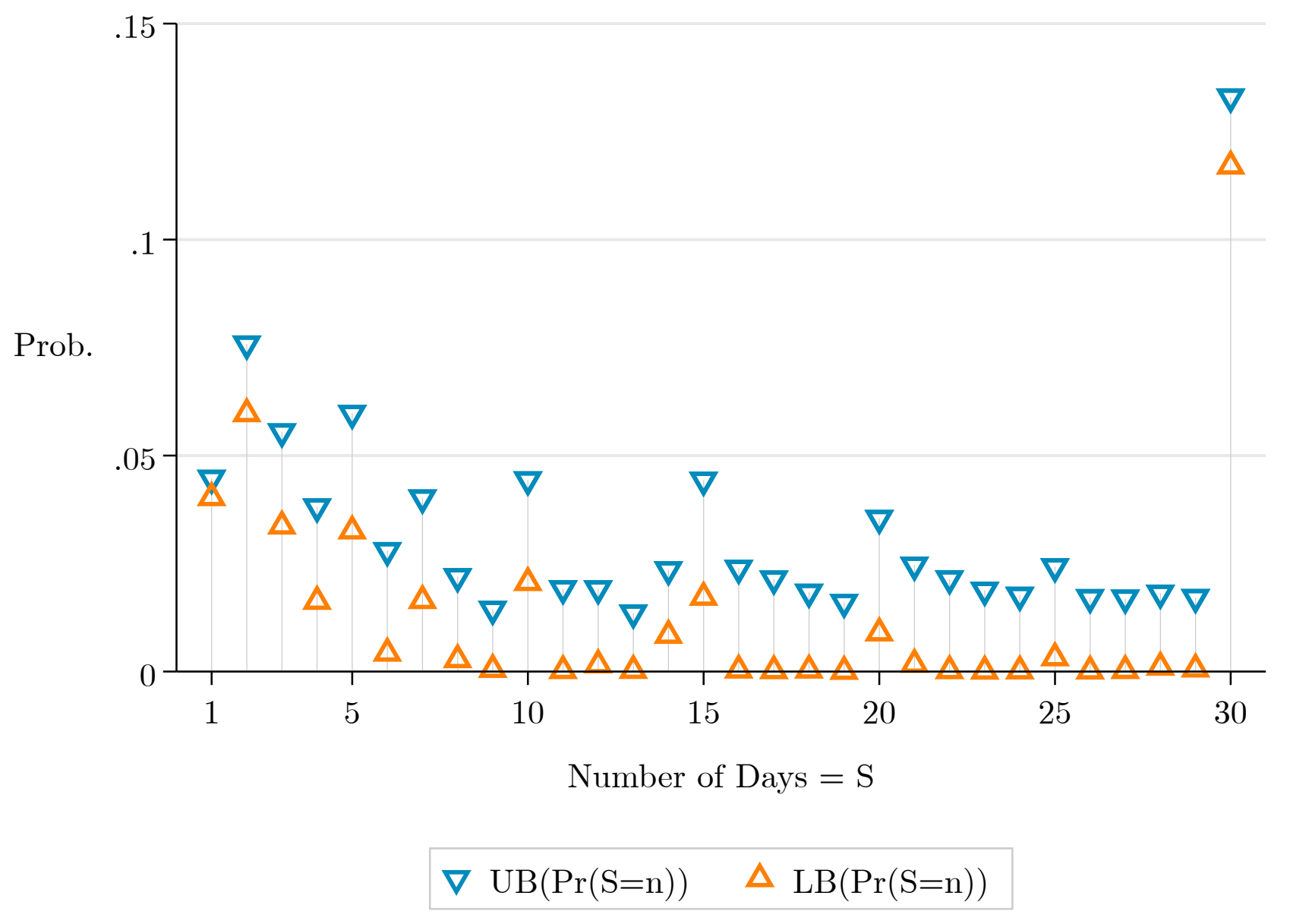


Figure 3

2015 HSE Sample: Sample Distributions of Vigorous, Moderate, and Walking Exercise Days

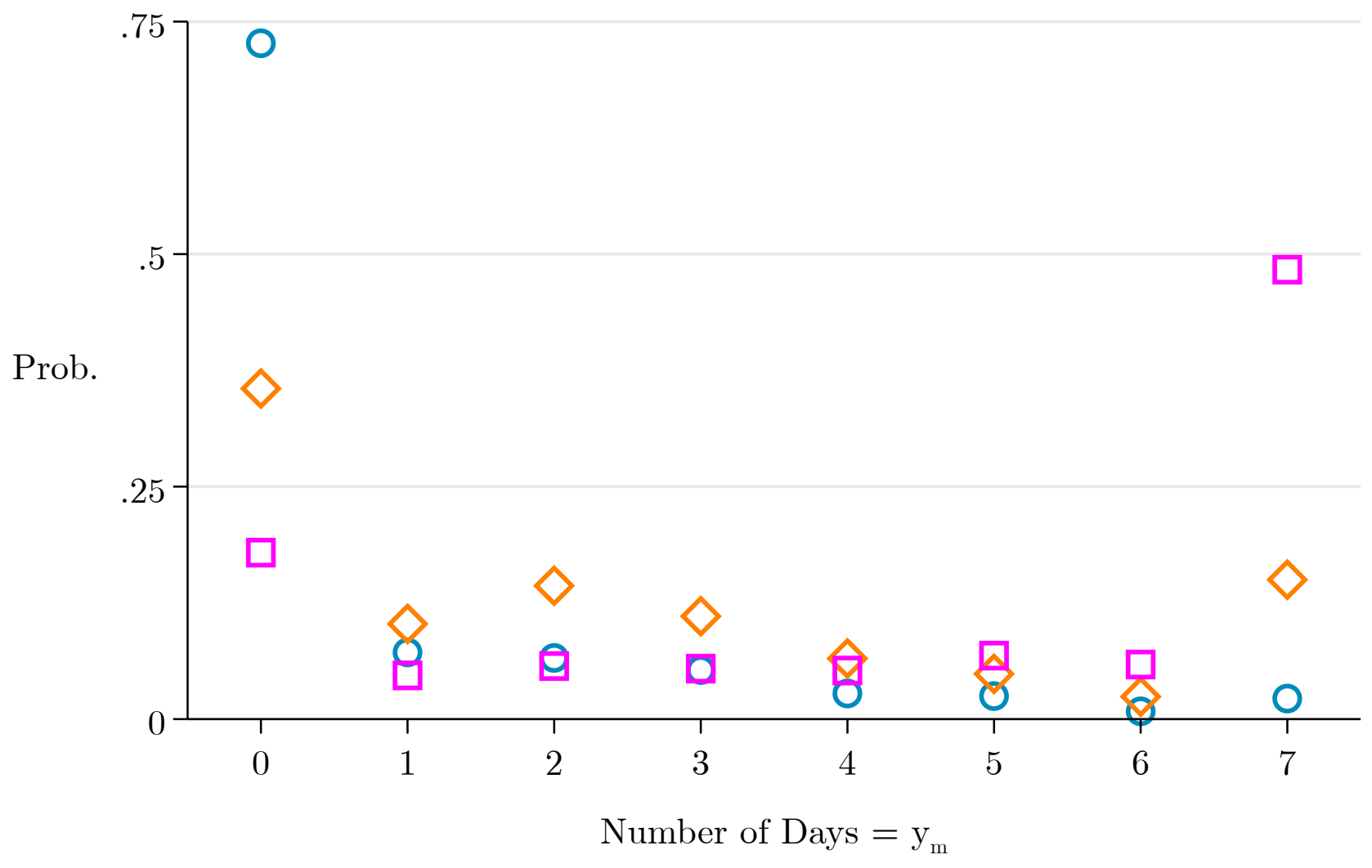

$\bigcirc$ Vigorous $\diamond$ Moderate $\square$ Walking


Figure 4

2015 HSE Sample: Upper and Lower Bounds on and Observed Values of $\operatorname{Pr}(S=n)$ for $n>0$; $\operatorname{Pr}(\mathrm{S}=0)$ is point-identified at .154

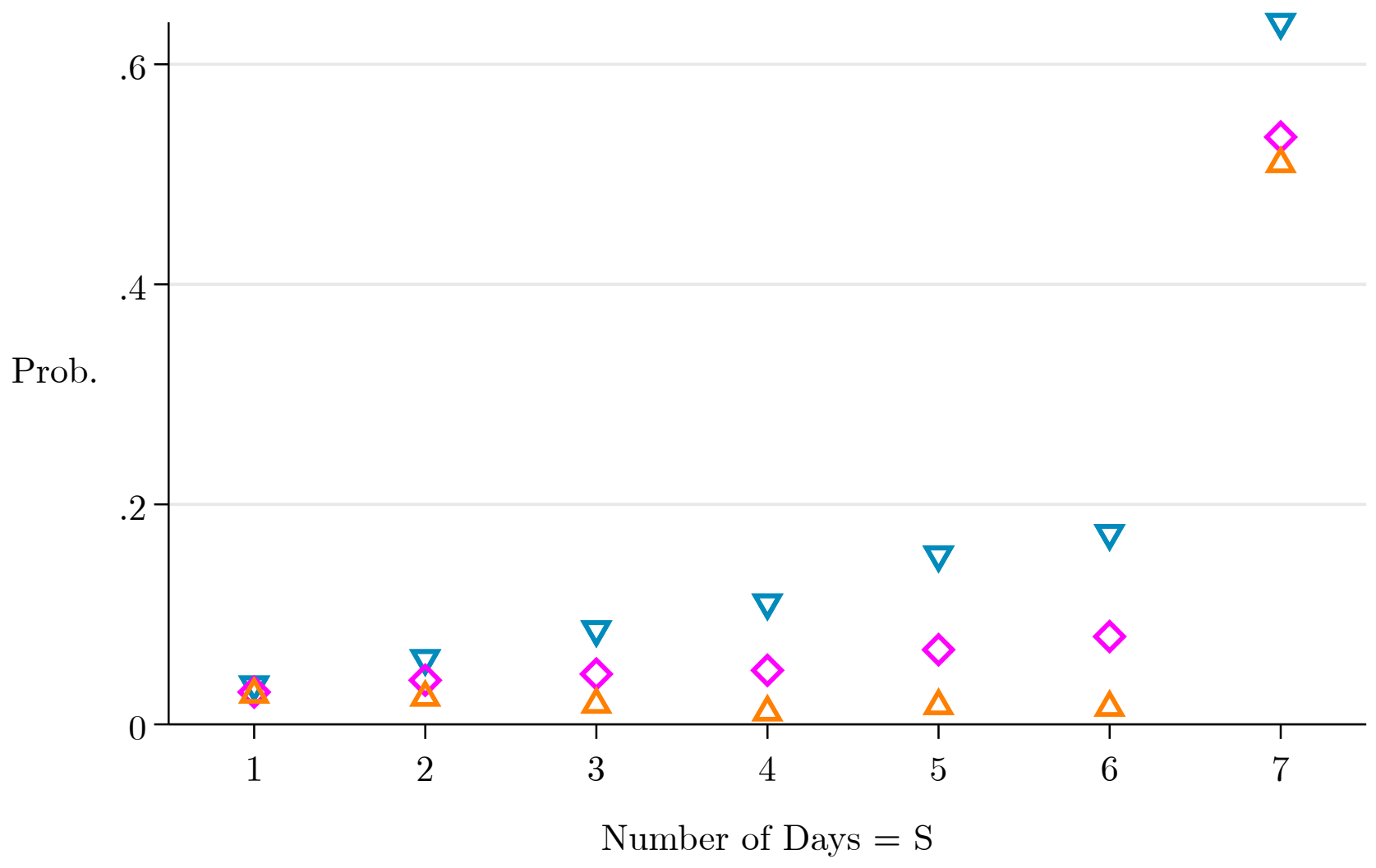

$$
\nabla \mathrm{UB}(\operatorname{Pr}(\mathrm{S}=\mathrm{n})) \quad \Delta \mathrm{LB}(\operatorname{Pr}(\mathrm{S}=\mathrm{n})) \quad \diamond \text { Observed } \operatorname{Pr}(\mathrm{S}=\mathrm{n})
$$


Figure 5

2017 YRBSS Sample: Sample Distributions of Cigarette, E-Cigs, Smokeless, and Cigar Use

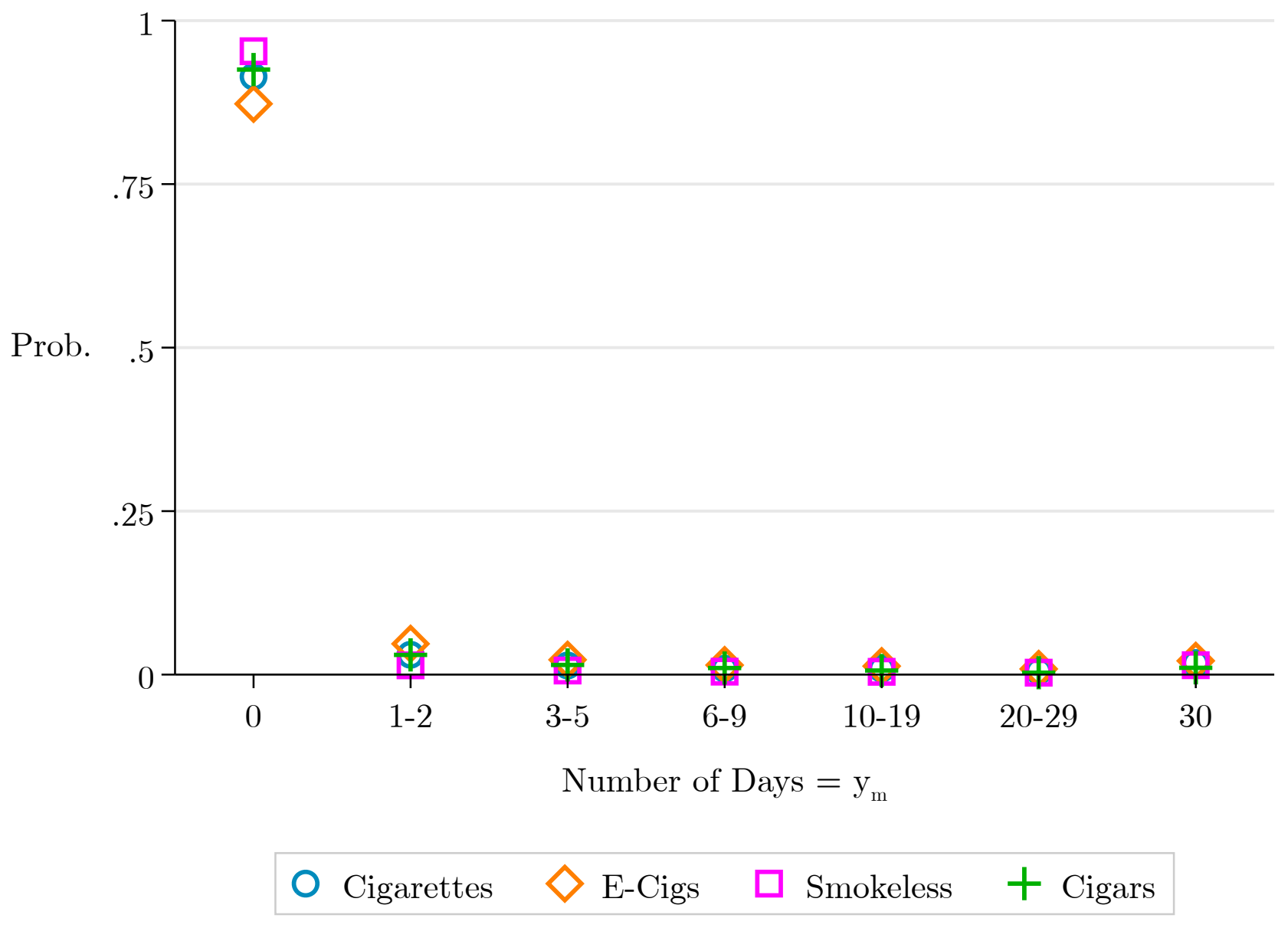


Figure 6

2017 YRBSS Sample: Upper and Lower Bounds on $\operatorname{Pr}\left(\mathrm{S} \in \mathrm{K}_{\mathrm{p}}\right)$ for $\mathrm{p}>1$;

$\operatorname{Pr}\left(\mathrm{S} \in \mathrm{K}_{1}\right)=\operatorname{Pr}(\mathrm{S}=0)$ is point-identified at .829

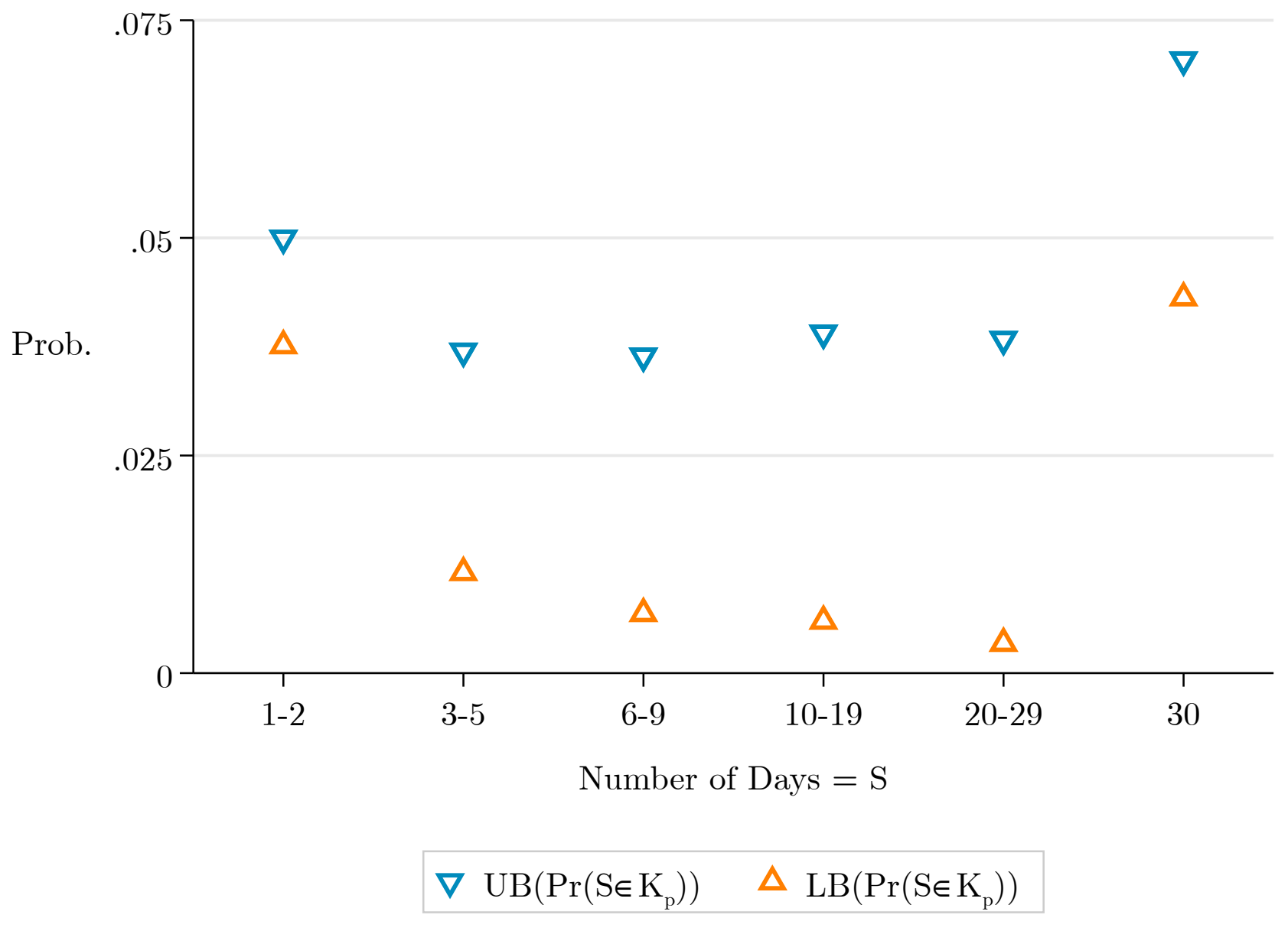


Table 1

Data Structure Summary

\begin{tabular}{|c|c|c|c|c|c|c|}
\hline & \multicolumn{4}{|c|}{ Event (m) } & \multirow{2}{*}{ Sum over $\mathrm{m}$} & \multirow{2}{*}{$\mathrm{S}_{\mathrm{n}}$} \\
\hline Unit (n) & 1 & 2 & $\ldots$ & $\mathrm{M}$ & & \\
\hline 1 & $\mathrm{y}_{1,1}$ & $\mathrm{y}_{2,1}$ & $\cdots$ & $\mathrm{y}_{\mathrm{M}, 1}$ & $\sum_{\mathrm{m} \in \mathcal{M}} \mathrm{y}_{\mathrm{m}, 1}$ & $1\left(\sum_{\mathrm{m} \in \mathcal{M}}^{\mathrm{y}_{\mathrm{m}, 1}}>0\right.$ \\
\hline 2 & $\mathrm{y}_{1,2}$ & $\mathrm{y}_{2,2}$ & $\cdots$ & $\mathrm{y}_{\mathrm{M}, 2}$ & $\sum_{\mathrm{m} \in \mathcal{M}} \mathrm{y}_{\mathrm{m}, 2}$ & $1\left(\sum_{\mathrm{m} \in \mathcal{M}} \mathrm{y}_{\mathrm{m}, 2}>0\right.$ \\
\hline ... & $\ldots$ & .. & $\ldots$ & .. & $\ldots$ & $\ldots$ \\
\hline $\mathrm{N}$ & $\mathrm{y}_{1, \mathrm{~N}}$ & $\mathrm{y}_{2, \mathrm{~N}}$ & $\cdots$ & $\mathrm{y}_{\mathrm{M}, \mathrm{N}}$ & $\sum_{\mathrm{m} \in \mathcal{M}} \mathrm{y}_{\mathrm{m}, \mathrm{N}}$ & $1\left(\sum_{\mathrm{m} \in \mathcal{M}} \mathrm{y}_{\mathrm{m}, \mathrm{N}}>0\right.$ \\
\hline Sum over $n$ & $\mathrm{y}_{1}$ & $\mathrm{y}_{2}$ & $\ldots$ & $\mathrm{y}_{\mathrm{M}}$ & & $\mathrm{S}$ \\
\hline
\end{tabular}


Table 2

Probabilities and Probability Assignments: An Example with $\mathrm{M}=2, \mathrm{~N}=3$

Panel A

\begin{tabular}{|c|c|c|c|c|c|}
\hline \multirow{2}{*}{\multicolumn{2}{|c|}{$\begin{array}{c}\text { Cell entries: Top row }=\text { joint } \\
\text { probability; bottom row }= \\
\text { possible values of } \mathrm{S}\end{array}$}} & \multicolumn{4}{|c|}{$\mathrm{y}_{1}$} \\
\hline & & 0 & 1 & 2 & 3 \\
\hline \multirow{4}{*}{$\mathrm{y}_{2}$} & 0 & $\begin{array}{c}\mathrm{p}_{0,0} \\
0 \\
\end{array}$ & $\begin{array}{c}\mathrm{p}_{1,0} \\
1 \\
\end{array}$ & $\begin{array}{c}\mathrm{p}_{2,0} \\
2 \\
\end{array}$ & $\begin{array}{c}\mathrm{p}_{3,0} \\
3 \\
\end{array}$ \\
\hline & 1 & $\begin{array}{c}\mathrm{p}_{0,1} \\
1\end{array}$ & $\begin{array}{l}\mathrm{p}_{1,1} \\
1,2\end{array}$ & $\begin{array}{l}\mathrm{p}_{2,1} \\
2,3\end{array}$ & $\begin{array}{c}\mathrm{p}_{3,1} \\
3\end{array}$ \\
\hline & 2 & $\begin{array}{c}\mathrm{p}_{0,2} \\
2 \\
\end{array}$ & $\begin{array}{l}\mathrm{p}_{1,2} \\
2,3 \\
\end{array}$ & $\begin{array}{l}\mathrm{p}_{2,2} \\
2,3 \\
\end{array}$ & $\begin{array}{c}\mathrm{p}_{3,2} \\
3 \\
\end{array}$ \\
\hline & 3 & $\begin{array}{c}\mathrm{p}_{0,3} \\
3\end{array}$ & $\begin{array}{c}\mathrm{p}_{1,3} \\
3\end{array}$ & $\begin{array}{c}\mathrm{p}_{2,3} \\
3\end{array}$ & $\begin{array}{c}\mathrm{p}_{3,3} \\
3\end{array}$ \\
\hline
\end{tabular}

Panel B

\begin{tabular}{|c|c|c|c|c|}
\hline \multirow[b]{2}{*}{$\mathrm{n}$} & \multicolumn{4}{|c|}{ Assigned Probabilities } \\
\hline & $\operatorname{Pr}_{\mathrm{L}}(\mathrm{n})$ & $\operatorname{Pr}_{\mathrm{E}, \mathrm{L}}(\mathrm{n})$ & $\operatorname{Pr}_{U}(n)$ & $\operatorname{Pr}_{\mathrm{E}, \mathrm{U}}(\mathrm{n})$ \\
\hline 0 & $\mathrm{p}_{0,0}$ & $\mathrm{p}_{0,0}$ & $\mathrm{p}_{0,0}$ & $\mathrm{p}_{0,0}$ \\
\hline 1 & $\mathrm{p}_{0,1}+\mathrm{p}_{1,0}$ & $\mathrm{p}_{0,1}+\mathrm{p}_{1,0}+\mathrm{p}_{1,1}$ & $\mathrm{p}_{0,1}+\mathrm{p}_{1,0}+\mathrm{p}_{1,1}$ & $\mathrm{p}_{0,1}+\mathrm{p}_{1,0}$ \\
\hline 2 & $\mathrm{p}_{0,2}+\mathrm{p}_{2,0}$ & $\begin{array}{c}\mathrm{p}_{0,2}+\mathrm{p}_{1,2}+\mathrm{p}_{2,0}+ \\
\mathrm{p}_{2,1}+\mathrm{p}_{2,2}\end{array}$ & $\begin{array}{c}\mathrm{p}_{0,2}+\mathrm{p}_{1,1}+\mathrm{p}_{1,2}+ \\
\mathrm{p}_{2,0}+\mathrm{p}_{2,1}+\mathrm{p}_{2,2}\end{array}$ & $\mathrm{p}_{0,2}+\mathrm{p}_{1,1}+\mathrm{p}_{2,0}$ \\
\hline 3 & $\begin{array}{c}\mathrm{p}_{0,3}+\mathrm{p}_{1,3}+\mathrm{p}_{2,3}+ \\
\mathrm{p}_{3,0}+\mathrm{p}_{3,1}+\mathrm{p}_{3,2}+ \\
\mathrm{p}_{3,3}\end{array}$ & $\begin{array}{c}\mathrm{p}_{0,3}+\mathrm{p}_{1,3}+\mathrm{p}_{2,3}+ \\
\mathrm{p}_{3,0}+\mathrm{p}_{3,1}+\mathrm{p}_{3,2}+ \\
\mathrm{p}_{3,3}\end{array}$ & $\begin{array}{c}\mathrm{p}_{0,3}+\mathrm{p}_{1,2}+\mathrm{p}_{1,3}+ \\
\mathrm{p}_{2,1}+\mathrm{p}_{2,2}+\mathrm{p}_{2,3}+ \\
\mathrm{p}_{3,0}+\mathrm{p}_{3,1}+\mathrm{p}_{3,2}+ \\
\mathrm{p}_{3,3}\end{array}$ & $\begin{array}{c}\mathrm{p}_{0,3}+\mathrm{p}_{1,2}+\mathrm{p}_{1,3} \\
\mathrm{p}_{2,1}+\mathrm{p}_{2,2}+\mathrm{p}_{2,3} \\
\mathrm{p}_{3,0}+\mathrm{p}_{3,1}+\mathrm{p}_{3,2} \\
\mathrm{p}_{3,3}\end{array}$ \\
\hline
\end{tabular}


Table 3

2017 BRFSS Sample: Observed E[ $\left.\mathrm{y}_{\mathrm{m}}\right]$ and Bounds on E[S] (Panel A); Quantile Bounds (Panel B)

Panel A

\begin{tabular}{|c|c|c|c|}
\hline \multicolumn{2}{|c|}{$\mathrm{E}\left[\mathrm{y}_{\mathrm{m}}\right]$} & \multicolumn{2}{|c|}{$\mathrm{E}[\mathrm{S}]$} \\
\hline Physically Unhealthy & Mentally Unhealthy & LB & UB \\
\hline 4.49 & 3.47 & 6.33 & 6.80 \\
\hline
\end{tabular}

Panel B

\begin{tabular}{|c|c|c|c|c|c|c|c|c|c|}
\hline & \multicolumn{10}{|c|}{$\alpha$} \\
\cline { 2 - 11 } & .1 & .2 & .3 & .4 & .5 & .6 & .7 & .8 & .9 \\
\hline LB & 0 & 0 & 0 & 0 & 1 & 2 & 5 & 14 & 30 \\
\hline UB & 0 & 0 & 0 & 0 & 1 & 3 & 5 & 15 & 30 \\
\hline
\end{tabular}


Table 4

2015 HSE Sample: Observed E[ $\left.\mathrm{y}_{\mathrm{m}}\right]$ and Bounds on and Observed Values of E[S] (Panel A); Quantile Bounds and Observed Quantiles (Panel B)

\section{Panel A}

\begin{tabular}{|c|c|c|c|c|c|}
\hline \multicolumn{3}{|c|}{$\mathrm{E}\left[\mathrm{y}_{\mathrm{m}}\right]$} & \multicolumn{3}{c|}{$\mathrm{E}[\mathrm{S}]$} \\
\hline Vigorous & Moderate & Walking & LB & UB & Observed \\
\hline 0.80 & 2.42 & 4.61 & 4.84 & 5.25 & 5.00 \\
\hline
\end{tabular}

Panel B

\begin{tabular}{|c|c|c|c|c|c|c|c|c|c|}
\hline & \multicolumn{10}{|c|}{$\alpha$} \\
\cline { 2 - 11 } & .1 & .2 & .3 & .4 & .5 & .6 & .7 & .8 & .9 \\
\hline LB & 0 & 2 & 3 & 5 & 7 & 7 & 7 & 7 & 7 \\
\hline UB & 0 & 2 & 5 & 7 & 7 & 7 & 7 & 7 & 7 \\
\hline Observed & 0 & 2 & 4 & 6 & 7 & 7 & 7 & 7 & 7 \\
\hline
\end{tabular}


Table 5

2017 BRFSS Sample: E[S|x $]$ Partial-Effect Bounds

\begin{tabular}{|c|c|c|c|c|c|c|c|}
\hline \multicolumn{2}{|c|}{$\begin{array}{c}\text { Age 25-64 } \rightarrow \\
\text { Age } 65+\end{array}$} & \multicolumn{2}{c|}{$\begin{array}{c}\text { Male } \rightarrow \\
\text { Female }\end{array}$} & \multicolumn{2}{c|}{$\begin{array}{c}\text { Not Coll. Grad. } \rightarrow \\
\text { Coll. Grad. }\end{array}$} & \multicolumn{2}{c|}{$\begin{array}{c}\text { Not White NH } \rightarrow \\
\text { White-NH }\end{array}$} \\
\hline LB & UB & LB & UB & LB & UB & LB & UB \\
\hline-0.91 & -0.02 & 0.91 & 1.81 & -3.37 & -2.48 & -0.83 & 0.13 \\
\hline
\end{tabular}


Table 6

2015 HSE Sample: E[S|x] Partial-Effect Bounds and Observed Values

\begin{tabular}{|c|c|c|c|c|c|c|c|c|c|c|c|}
\hline \multicolumn{2}{|c|}{$\begin{array}{c}\text { Age 25-49 } \rightarrow \\
\text { Age 50+ }\end{array}$} & \multicolumn{3}{c|}{$\begin{array}{c}\text { Male } \rightarrow \\
\text { Female }\end{array}$} & \multicolumn{3}{c|}{$\begin{array}{c}\text { Not Coll. Degree } \rightarrow \\
\text { Coll. Degree }\end{array}$} & \multicolumn{4}{c|}{$\begin{array}{c}\text { North } \rightarrow \\
\text { South }\end{array}$} \\
\hline LB & UB & Obs. & LB & UB & Obs. & LB & UB & Obs. & LB & UB & Obs. \\
\hline-0.92 & -0.09 & -0.50 & -0.36 & 0.46 & 0.05 & 0.21 & 1.12 & 0.63 & -0.16 & 0.67 & 0.25 \\
\hline
\end{tabular}


Table 7

2017 YRBSS Sample: Bounds on E[ $\left.\mathrm{y}_{\mathrm{m}}\right]$ and E[S]

\begin{tabular}{|c|c|c|c|c|c|c|c|c|c|}
\hline \multicolumn{9}{|c|}{$\mathrm{E}\left[\mathrm{y}_{\mathrm{m}}\right]$} & \multicolumn{4}{|c|}{$\mathrm{E}[\mathrm{S}]$} \\
\hline \multicolumn{2}{|c|}{ Cigarettes } & \multicolumn{2}{|c|}{ E-Cigs } & \multicolumn{2}{c|}{ Smokeless } & \multicolumn{2}{c|}{ Cigars } & \multicolumn{3}{|c|}{ UB } & UB \\
\hline LB & UB & LB & UB & LB & UB & LB & UB & LB \\
\hline 0.86 & 1.07 & 1.15 & 1.48 & 0.58 & 0.69 & 0.55 & 0.73 & 2.02 & 3.05 \\
\hline
\end{tabular}


Table A1

2017 BRFSS Sample: Observed $\operatorname{Pr}\left(\mathrm{y}_{\mathrm{m}}=\mathrm{n}\right)$; Bounds on $\operatorname{Pr}(\mathrm{S}=\mathrm{n})$

\begin{tabular}{|c|c|c|c|c|c|c|}
\hline \multirow[b]{2}{*}{$\mathrm{n}$} & \multicolumn{2}{|c|}{$\operatorname{Pr}\left(\mathrm{y}_{\mathrm{m}}=\mathrm{n}\right)$} & \multicolumn{2}{|c|}{$\operatorname{Pr}(\mathrm{S}=\mathrm{n})$} & \multirow[b]{2}{*}{$\operatorname{Pr}_{\mathrm{E}, \mathrm{L}}(\mathrm{n})$} & \multirow[b]{2}{*}{$\operatorname{Pr}_{\mathrm{E}, \mathrm{U}}(\mathrm{n})$} \\
\hline & $\begin{array}{l}\text { Physically } \\
\text { Unhealthy }\end{array}$ & $\begin{array}{l}\text { Mentally } \\
\text { Unhealthy }\end{array}$ & LB & UB & & \\
\hline 0 & .6261 & .6887 & .4942 & .4942 & .4942 & .4942 \\
\hline 1 & .0410 & .0313 & .0403 & .0447 & .0447 & .0403 \\
\hline 2 & .0569 & .0482 & .0597 & .0758 & .0713 & .0642 \\
\hline 3 & .0332 & .0279 & .0337 & .0555 & .0439 & .0404 \\
\hline 4 & .0175 & .0141 & .0163 & .0381 & .0231 & .0249 \\
\hline 5 & .0298 & .0343 & .0326 & .0598 & .0465 & .0387 \\
\hline 6 & .0051 & .0040 & .0043 & .0280 & .0069 & .0120 \\
\hline 7 & .0184 & .0128 & .0164 & .0402 & .0241 & .0228 \\
\hline 8 & .0033 & .0027 & .0028 & .0220 & .0046 & .0084 \\
\hline 9 & .0007 & .0004 & .0005 & .0144 & .0009 & .0044 \\
\hline 10 & .0225 & .0249 & .0206 & .0444 & .0343 & .0256 \\
\hline 11 & .0003 & .0002 & .0002 & .0192 & .0004 & .0031 \\
\hline 12 & .0024 & .0018 & .0016 & .0192 & .0031 & .0061 \\
\hline 13 & .0003 & .0003 & .0003 & .0136 & .0005 & .0026 \\
\hline 14 & .0107 & .0050 & .0084 & .0236 & .0127 & .0111 \\
\hline 15 & .0208 & .0236 & .0172 & .0443 & .0318 & .0211 \\
\hline 16 & .0006 & .0004 & .0004 & .0239 & .0007 & .0030 \\
\hline 17 & .0004 & .0003 & .0002 & .0214 & .0005 & .0039 \\
\hline 18 & .0007 & .0005 & .0004 & .0184 & .0008 & .0025 \\
\hline 19 & .0001 & .0001 & .0001 & .0160 & .0001 & .0016 \\
\hline 20 & .0137 & .0143 & .0090 & .0355 & .0211 & .0135 \\
\hline 21 & .0025 & .0008 & .0017 & .0246 & .0027 & .0036 \\
\hline 22 & .0003 & .0003 & .0002 & .0215 & .0005 & .0029 \\
\hline 23 & .0002 & .0001 & .0001 & .0188 & .0002 & .0015 \\
\hline 24 & .0003 & .0002 & .0002 & .0177 & .0004 & .0014 \\
\hline 25 & .0054 & .0050 & .0032 & .0243 & .0080 & .0075 \\
\hline 26 & .0003 & .0002 & .0001 & .0171 & .0004 & .0008 \\
\hline 27 & .0005 & .0004 & .0003 & .0170 & .0007 & .0015 \\
\hline 28 & .0019 & .0014 & .0010 & .0181 & .0026 & .0024 \\
\hline 29 & .0010 & .0008 & .0006 & .0172 & .0014 & .0012 \\
\hline 30 & .0830 & .0550 & .1170 & .1330 & .1170 & .1330 \\
\hline
\end{tabular}


Table A2

2015 HSE Sample: Observed $\operatorname{Pr}\left(\mathrm{y}_{\mathrm{m}}=\mathrm{n}\right)$; Bounds on and Observed Values of $\operatorname{Pr}(\mathrm{S}=\mathrm{n})$

\begin{tabular}{|c|c|c|c|c|c|c|c|c|}
\hline \multirow{2}{*}{$\mathrm{n}$} & \multicolumn{3}{|c|}{$\operatorname{Pr}\left(\mathrm{y}_{\mathrm{m}}=\mathrm{n}\right)$} & \multicolumn{3}{c|}{$\operatorname{Pr}(\mathrm{S}=\mathrm{n})$} & \multirow{2}{*}{$\operatorname{Pr}_{\mathrm{E}, \mathrm{L}}(\mathrm{n})$} & $\operatorname{Pr}_{\mathrm{E}, \mathrm{U}}(\mathrm{n})$ \\
\cline { 2 - 8 } & Vigorous & Moderate & Walking & LB & UB & Obs. & .1541 \\
\hline 0 & .7267 & .3555 & .1790 & .1541 & .1541 & .1541 & .1541 & .1541 \\
\hline 1 & .0717 & .1024 & .0471 & .0273 & .0360 & .0294 & .0360 & .0273 \\
\hline 2 & .0658 & .1434 & .0571 & .0245 & .0599 & .0401 & .0512 & .0326 \\
\hline 3 & .0528 & .1107 & .0543 & .0181 & .0862 & .0457 & .0589 & .0316 \\
\hline 4 & .0276 & .0652 & .0522 & .0111 & .1105 & .0491 & .0559 & .0304 \\
\hline 5 & .0248 & .0487 & .0683 & .0168 & .1541 & .0679 & .0739 & .0409 \\
\hline 6 & .0084 & .0242 & .0587 & .0153 & .1737 & .0798 & .0605 & .0450 \\
\hline 7 & .0221 & .1499 & .4833 & .5095 & .6382 & .5339 & .5095 & .6382 \\
\hline
\end{tabular}


Table A3

2017 BRFSS Sample: $\operatorname{Pr}(\mathrm{S}=\mathrm{n} \mid \mathbf{x})$ Partial-Effect Bounds

\begin{tabular}{|c|c|c|c|c|c|c|c|c|}
\hline \multirow{2}{*}{$\mathrm{n}$} & \multicolumn{2}{|c|}{$\begin{array}{c}\text { Age } 25-64 \rightarrow \\
\text { Age } 65+\end{array}$} & \multicolumn{2}{|c|}{$\begin{array}{l}\text { Male } \rightarrow \\
\text { Female }\end{array}$} & \multicolumn{2}{|c|}{$\begin{array}{c}\text { Not Coll. Grad. } \rightarrow \\
\text { Coll. Grad. }\end{array}$} & \multicolumn{2}{|c|}{$\begin{array}{c}\text { Not White } \mathrm{NH} \rightarrow \\
\text { White-NH }\end{array}$} \\
\hline & LB & UB & LB & UB & LB & UB & LB & UB \\
\hline 0 & .0771 & .0771 & -.0977 & -.0977 & .0520 & .0520 & -.0115 & -.0115 \\
\hline 1 & -.0175 & -.0092 & -.0015 & .0073 & .0177 & .0271 & .0051 & .0136 \\
\hline 2 & -.0306 & -.0005 & -.0077 & .0240 & .0033 & .0371 & -.0031 & .0283 \\
\hline 3 & -.0305 & .0102 & -.0138 & .0289 & -.0120 & .0330 & -.0198 & .0236 \\
\hline 4 & -.0263 & .0148 & -.0170 & .0259 & -.0180 & .0266 & -.0197 & .0234 \\
\hline 5 & -.0364 & .0150 & -.0152 & .0381 & -.0197 & .0354 & -.0202 & .0334 \\
\hline 6 & -.0264 & .0186 & -.0190 & .0275 & -.0227 & .0251 & -.0220 & .0244 \\
\hline 7 & -.0282 & .0168 & -.0143 & .0320 & -.0252 & .0223 & -.0292 & .0190 \\
\hline 8 & -.0216 & .0150 & -.0149 & .0225 & -.0199 & .0183 & -.0222 & .0177 \\
\hline 9 & -.0159 & .0106 & -.0105 & .0166 & -.0145 & .0130 & -.0166 & .0128 \\
\hline 10 & -.0265 & .0192 & -.0149 & .0315 & -.0263 & .0207 & -.0230 & .0256 \\
\hline 11 & -.0215 & .0151 & -.0145 & .0225 & -.0200 & .0175 & -.0200 & .0189 \\
\hline 12 & -.0197 & .0144 & -.0137 & .0206 & -.0193 & .0154 & -.0191 & .0174 \\
\hline 13 & -.0149 & .0110 & -.0103 & .0157 & -.0149 & .0110 & -.0151 & .0129 \\
\hline 14 & -.0158 & .0136 & -.0090 & .0207 & -.0194 & .0100 & -.0206 & .0118 \\
\hline 15 & -.0310 & .0214 & -.0182 & .0347 & -.0364 & .0159 & -.0308 & .0256 \\
\hline 16 & -.0271 & .0183 & -.0177 & .0282 & -.0274 & .0177 & -.0264 & .0228 \\
\hline 17 & -.0243 & .0167 & -.0161 & .0253 & -.0250 & .0155 & -.0241 & .0205 \\
\hline 18 & -.0206 & .0143 & -.0136 & .0216 & -.0217 & .0126 & -.0206 & .0173 \\
\hline 19 & -.0181 & .0130 & -.0120 & .0192 & -.0194 & .0109 & -.0183 & .0154 \\
\hline 20 & -.0308 & .0204 & -.0183 & .0334 & -.0354 & .0149 & -.0290 & .0258 \\
\hline 21 & -.0262 & .0178 & -.0162 & .0285 & -.0286 & .0147 & -.0252 & .0222 \\
\hline 22 & $\begin{array}{r}-.0249 \\
\end{array}$ & .0161 & -.0156 & .0259 & -.0263 & .0138 & -.0234 & .0208 \\
\hline 23 & -.0218 & .0143 & -.0136 & .0229 & -.0233 & .0118 & -.0206 & .0183 \\
\hline 24 & -.0205 & .0133 & -.0127 & .0214 & -.0220 & .0107 & -.0195 & .0170 \\
\hline 25 & -.0240 & .0167 & -.0143 & .0267 & -.0276 & .0118 & -.0228 & .0209 \\
\hline 26 & -.0199 & .0128 & -.0125 & .0206 & -.0216 & .0100 & -.0186 & .0166 \\
\hline 27 & -.0196 & .0127 & -.0123 & .0204 & -.0215 & .0097 & -.0187 & .0162 \\
\hline 28 & -.0200 & .0131 & -.0125 & .0209 & -.0225 & .0092 & -.0186 & .0170 \\
\hline 29 & -.0190 & .0132 & -.0124 & .0199 & -.0216 & .0090 & -.0181 & .0163 \\
\hline 30 & -.0134 & .0176 & .0045 & .0356 & -.0968 & -.0672 & -.0268 & .0063 \\
\hline
\end{tabular}


Table A4

2015 HSE Sample: $\operatorname{Pr}(\mathrm{S}=\mathrm{n} \mid \mathbf{x})$ Partial-Effect Bounds and Observed Values

\begin{tabular}{|c|c|c|c|c|c|c|c|c|c|c|c|c|}
\hline \multirow{2}{*}{$\mathrm{n}$} & \multicolumn{3}{|c|}{$\begin{array}{l}\text { Age } 25-49 \rightarrow \\
\text { Age } 50+\end{array}$} & \multicolumn{3}{|c|}{$\begin{array}{l}\text { Male } \rightarrow \\
\text { Female }\end{array}$} & \multicolumn{3}{|c|}{$\begin{array}{c}\text { Not Coll. Degree } \rightarrow \\
\text { Coll. Degree }\end{array}$} & \multicolumn{3}{|c|}{$\begin{array}{l}\text { North } \rightarrow \\
\text { South }\end{array}$} \\
\hline & $\mathrm{LB}$ & $\mathrm{UB}$ & Obs. & LB & UB & Obs. & $\mathrm{LB}$ & UB & Obs. & LB & UB & Obs. \\
\hline 0 & .0425 & 425 & .0425 & .0182 & -.0182 & -.0182 & .0946 & -.0946 & -.0946 & .0262 & -.0262 & -.0262 \\
\hline 1 & .0100 & 268 & & & 3 & & 9 & -.0016 & -.0 & & & \\
\hline 2 & 0214 & .0489 & .0 & -.0 & .0350 & .0 & -.0410 & .0296 & -.0054 & -.0414 & 44 & -.0056 \\
\hline 3 & 0584 & .0764 & $.010^{\prime}$ & -.0665 & .0689 & -.0023 & -.0709 & .0672 & -.0006 & -.0721 & .0653 & -.0001 \\
\hline 4 & -.0948 & .1043 & .0092 & -.0843 & .1124 & .0114 & -.0864 & .1312 & .0221 & -.1036 & .0975 & -.0037 \\
\hline 0 & -.1498 & .1290 & -.00 & -.12 & .1493 & & -.1191 & .1925 & .0267 & -.1398 & .1367 & -.0016 \\
\hline 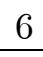 & -.1774 & .1455 & -.01 & -.14 & & & -.1446 & .2033 & .0072 & -.1540 & .1632 & .0045 \\
\hline 7 & -.2058 & .0574 & -.0702 & -.1394 & .1156 & -.0211 & -.0708 & .2102 & .0562 & -.0929 & .1645 & .0379 \\
\hline
\end{tabular}


Table A5

2017 YRBSS Sample: Observed $\operatorname{Pr}\left(\mathrm{y}_{\mathrm{m}} \in \mathrm{K}_{\mathrm{p}}\right)$; Bounds on $\operatorname{Pr}(\mathrm{S}=\mathrm{n})$

\begin{tabular}{|c|c|c|c|c|c|c|c|c|c|}
\hline \multirow{2}{*}{$\mathrm{K}_{\mathrm{p}}$} & \multirow[b]{2}{*}{$\mathrm{n}$} & \multicolumn{4}{|c|}{$\operatorname{Pr}\left(\mathrm{y}_{\mathrm{m}} \in \mathrm{K}_{\mathrm{p}}\right)$} & \multicolumn{2}{|c|}{$\operatorname{Pr}(\mathrm{S}=\mathrm{n})$} & \multirow{2}{*}{$\operatorname{Pr}_{\mathrm{E}, \mathrm{L}}(\mathrm{n})$} & \multirow{2}{*}{$\operatorname{Pr}_{\mathrm{E}, \mathrm{U}}(\mathrm{n})$} \\
\hline & & Cigarettes & E-Cigs & Smokeless & Cigars & LB & UB & & \\
\hline 0 & 0 & .9144 & .8728 & .9532 & .9252 & .8286 & .8286 & .8286 & .8286 \\
\hline \multirow{2}{*}{$1-2$} & 1 & .0304 & .0471 & .0142 & .0302 & .0376 & .0500 & .0500 & 0 \\
\hline & 2 & .0304 & .0471 & .0142 & .0302 & .0376 & .0500 & 0 & .0376 \\
\hline \multirow{3}{*}{$3-5$} & 3 & .0139 & .0227 & .0063 & .0148 & .0116 & .0370 & .0246 & 0 \\
\hline & 4 & .0139 & .0227 & .0063 & .0148 & .0116 & .0370 & 0 & 0 \\
\hline & 5 & .0139 & .0227 & .0063 & .0148 & .0116 & .0370 & 0 & .0209 \\
\hline \multirow{4}{*}{$6-9$} & 6 & .0091 & .0146 & .0045 & .0101 & .0069 & .0364 & .0203 & 0 \\
\hline & 7 & .0091 & .0146 & .0045 & .0101 & .0069 & .0364 & 0 & 0 \\
\hline & 8 & .0091 & .0146 & .0045 & .0101 & .0069 & .0364 & 0 & 0 \\
\hline & 9 & .0091 & .0146 & .0045 & .0101 & .0069 & .0364 & 0 & .0163 \\
\hline \multirow{10}{*}{$10-19$} & 10 & .0090 & .0130 & .0043 & .0063 & .0060 & .0391 & .0189 & 0 \\
\hline & 11 & .0090 & .0130 & .0043 & .0063 & .0060 & .0391 & 0 & 0 \\
\hline & 12 & .0090 & .0130 & .0043 & .0063 & .0060 & .0391 & 0 & 0 \\
\hline & 13 & .0090 & .0130 & .0043 & .0063 & .0060 & .0391 & 0 & 0 \\
\hline & 14 & .0090 & .0130 & .0043 & .0063 & .0060 & .0391 & 0 & 0 \\
\hline & 15 & .0090 & .0130 & .0043 & .0063 & .0060 & .0391 & 0 & 0 \\
\hline & 16 & .0090 & .0130 & .0043 & .0063 & .0060 & .0391 & 0 & 0 \\
\hline & 17 & .0090 & .0130 & .0043 & .0063 & .0060 & .0391 & 0 & 0 \\
\hline & 18 & .0090 & .0130 & .0043 & .0063 & .0060 & .0391 & 0 & 0 \\
\hline & 19 & .0090 & .0130 & .0043 & .0063 & .0060 & .0391 & 0 & .0152 \\
\hline \multirow{10}{*}{$20-29$} & 20 & .0054 & .0087 & .0030 & .0029 & .0034 & .0383 & .0145 & 0 \\
\hline & 21 & .0054 & .0087 & .0030 & .0029 & .0034 & .0383 & 0 & 0 \\
\hline & 22 & .0054 & .0087 & .0030 & .0029 & .0034 & .0383 & 0 & 0 \\
\hline & 23 & .0054 & .0087 & .0030 & .0029 & .0034 & .0383 & 0 & 0 \\
\hline & 24 & .0054 & .0087 & .0030 & .0029 & .0034 & .0383 & 0 & 0 \\
\hline & 25 & .0054 & .0087 & .0030 & .0029 & .0034 & .0383 & 0 & 0 \\
\hline & 26 & .0054 & .0087 & .0030 & .0029 & .0034 & .0383 & 0 & 0 \\
\hline & 27 & .0054 & .0087 & .0030 & .0029 & .0034 & .0383 & 0 & 0 \\
\hline & 28 & .0054 & .0087 & .0030 & .0029 & .0034 & .0383 & 0 & 0 \\
\hline & 29 & .0054 & .0087 & .0030 & .0029 & .0034 & .0383 & 0 & .0110 \\
\hline 30 & 30 & .0178 & .0211 & .0144 & .0104 & .0431 & .0704 & .0431 & .0704 \\
\hline
\end{tabular}

